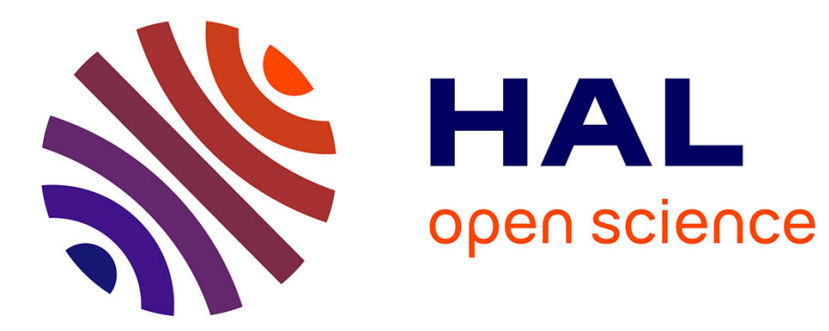

\title{
Propane dissociation in a non-thermal high-pressure nitrogen plasma
}

N Moreau, S Pasquiers, N Blin-Simiand, L Magne, F Jorand, C Postel, J-R Vacher

\section{- To cite this version:}

N Moreau, S Pasquiers, N Blin-Simiand, L Magne, F Jorand, et al.. Propane dissociation in a non-thermal high-pressure nitrogen plasma. Journal of Physics D: Applied Physics, 2010, 43 (28), pp.285201. 10.1088/0022-3727/43/28/285201 . hal-00569649

\section{HAL Id: hal-00569649 \\ https://hal.science/hal-00569649}

Submitted on 25 Feb 2011

HAL is a multi-disciplinary open access archive for the deposit and dissemination of scientific research documents, whether they are published or not. The documents may come from teaching and research institutions in France or abroad, or from public or private research centers.
L'archive ouverte pluridisciplinaire HAL, est destinée au dépôt et à la diffusion de documents scientifiques de niveau recherche, publiés ou non, émanant des établissements d'enseignement et de recherche français ou étrangers, des laboratoires publics ou privés. 


\title{
Propane dissociation in a non-thermal high pressure nitrogen plasma
}

\author{
N Moreau, S Pasquiers, N Blin-Simiand, L Magne, F Jorand, C Postel, and J-R \\ Vacher \\ Laboratoire de Physique des Gaz et des Plasmas \\ CNRS (UMR8578) \\ Université Paris-Sud, Bâtiment 210. 91405 Orsay Cedex, France \\ E-mail address: stephane.pasquiers@u-psud.fr
}

\begin{abstract}
The removal and the conversion processes of propane in $\mathrm{N}_{2} / \mathrm{C}_{3} \mathrm{H}_{8}$ mixtures (concentration of hydrocarbon molecules up to $5500 \mathrm{ppm}$ ) energised by a photo-triggered discharge (homogeneous plasma) are studied at 460 mbar total pressure, both experimentally and theoretically. A self-consistent $0 \mathrm{D}$ discharge and kinetic model is used to interpret chromatographic measurements of propane and some by-products concentrations (hydrogen and hydrocarbons with 2 or 3 carbon atoms). It is suggested, from the comparison between measurements and model predictions, that quenching processes of nitrogen metastable states by $\mathrm{C}_{3} \mathrm{H}_{8}$ lead to the dissociation of the hydrocarbon molecule, and are the most important processes for the removal of propane. Such a result is obtained using the quenching coefficient value previously determined by Callear and Wood for the $\mathrm{A}^{3} \Sigma^{+}{ }_{\mathrm{u}}$ state [19], whereas the coefficient for collisions of the singlet states with $\mathrm{C}_{3} \mathrm{H}_{8}$ is estimated to be $3.0 \times 10^{-10} \mathrm{~cm}^{3} \mathrm{~s}^{-1}$ in order to explain the measured propane disappearance in the $\mathrm{N}_{2} / \mathrm{C}_{3} \mathrm{H}_{8}$ mixture excited by the photo-triggered discharge. The hydrogen molecule is the measured most populated by-product and, also from the comparison between experimental results and model predictions, the most probable dissociation products of propane appear to be $\mathrm{H}_{2}$ and $\mathrm{C}_{3} \mathrm{H}_{6}$. The propene molecule is also efficiently dissociated by quenching processes of $\mathrm{N}_{2}$ states, and probably leads to the production of hydrogen atoms and methyl radicals with equivalent probabilities. The kinetic model predicts that the carbon atom is distributed amongst numerous molecules, including $\mathrm{HCN}, \mathrm{CH}_{4}, \mathrm{C}_{2} \mathrm{H}_{2}, \mathrm{C}_{2} \mathrm{H}_{4}, \mathrm{C}_{2} \mathrm{H}_{6}, \mathrm{C}_{3} \mathrm{H}_{6}$.
\end{abstract}

PACS : 52.77.Fv - 82.33.Xj

Keywords : High pressure non-thermal plasmas, nitrogen metastable states, propane, plasma kinetic, photo-triggered discharge.

Submitted to : Journal of Physics D: Applied Physics 


\section{Introduction}

The kinetic of propane in non-thermal plasmas of atmospheric gases $\left(\mathrm{N}_{2} / \mathrm{O}_{2} / \mathrm{H}_{2} \mathrm{O}\right.$ mixtures $)$ is currently under study owing to various applications such as cleaning of polluted air streams [1-6], or more recently plasma assisted ignition and combustion [7-13]. Owing to other types of previously developed applications of low pressure plasmas, for example carbon compounds thin films production [14], numerous works have been performed in the past about electron collisions on this hydrocarbon molecule [15-18], especially on ionisation processes. However, there is a lack of knowledge about dissociation processes of propane, in particular through quenching collisions of the nitrogen metastable electronic states $[19,20]$, in high-pressure and low temperature pulsed discharge plasmas of molecular gases. In order to get more information about such processes, which could be involved in plasmas used for ignition or used for treatment of flue gases coming from combustion, we have studied the conversion kinetic of propane in the binary $\mathrm{N}_{2} / \mathrm{C}_{3} \mathrm{H}_{8}$ mixture energised by a phototriggered discharge.

The photo-triggering technique allows to achieve homogeneous transient high-pressure plasmas in various types of gas mixtures and at various total pressure values, typically ranging from 100 mbars up to several bars [21]. Measurements can be compared with confidence to predictions of a self-consistent OD discharge and kinetic model which takes into account all relevant reactions for the hydrocarbon molecule. We have recently used such a discharge and modelling to study the production and reactivity of the hydroxyl radical in $\mathrm{N}_{2} / \mathrm{O}_{2}$ mixture with addition of VOCs (acetone or isopropyl alcohol) [22] or light olefins (ethene and ethane) [23, 24]. It was shown that $\mathrm{N}_{2}$ metastable states $\left(\mathrm{A}^{3} \Sigma^{+}\right.$u , with an excitation threshold at $6.17 \mathrm{eV}$, but also singlets : a ${ }^{1} \Sigma^{-}$, a ${ }^{1} \Pi_{\mathrm{g}}$, and $\mathrm{w}^{1} \Delta_{\mathrm{u}}$, with a threshold at $8.4 \mathrm{eV}$ ) play an important role in the kinetic chain leading to the production of $\mathrm{OH}$, owing to dissociative quenching collisions of these states on the carbonated molecules. Such processes must be taken into account to explain the degradation of VOCs and hydrocarbons. For ethane, the corresponding rate constant for the singlet states has been estimated to be a factor of 300 higher than the one for the A state [24]. The higher rate constant for the quenching of singlets than for $\mathrm{A}^{3} \Sigma^{+}{ }_{\mathrm{u}}$ has been previously demonstrated for methane [25] and for ethene [26]. The most probable exit channel for quenching collisions by ethane appears to be the production of ethene and hydrogen molecules. Afterwards $\mathrm{C}_{2} \mathrm{H}_{4}$ is dissociated by same types of processes, to produce $\mathrm{H}$ and $\mathrm{H}_{2}$ with similar rate constants [24].

In the present work, we discuss about the role of $\mathrm{N}_{2}$ states quenching collisions on the conversion of propane. Oxygen was not added to the $\mathrm{N}_{2} / \mathrm{C}_{3} \mathrm{H}_{8}$ mixture in order to avoid oxidation of the hydrocarbon by reactions with $\mathrm{O}$-atoms, either in ${ }^{3} \mathrm{P}$ or in ${ }^{1} \mathrm{D}$ states, and by reactions with $\mathrm{OH}$ which can be efficiently produced by the three body $\mathrm{H}$-and $\mathrm{O}$-atoms recombination process [23]. Through comparison between measurements and predictions of the 0D-model, a rate constant for the collision of the singlet states with $\mathrm{C}_{3} \mathrm{H}_{8}$ is estimated (the rate constant for the A state is known [19]), and possible exit pathways are proposed for both reactions involving $\mathrm{A}$ and singlet states. Concentrations of molecular products $\left(\mathrm{H}_{2}, \mathrm{CH}_{4}, \mathrm{C}_{2} \mathrm{H}_{6}, \mathrm{C}_{3} \mathrm{H}_{6}\right.$, and unsaturated $\mathrm{C}_{2}$ compounds) are measured together with the residual propane concentration, once the reactivity of the excited medium has ended, as function of the initial concentration of hydrocarbon molecules in nitrogen. Dissociation processes of one of these products, propene, are also examined.

\section{Experimental set-up}

The photo-triggered reactor used in the present study, called "UV510", has been described in previous publications [21-24]. It allows to create an homogeneous plasma volume, $V_{D}$, of $50 \mathrm{~cm}^{3}$, with a discharge current pulse of $60 \mathrm{~ns}$ for duration. The total pressure of the studied mixtures is fixed to 460 mbar, at ambient temperature, and the initial propane concentration in nitrogen is chosen between 200 and $5500 \mathrm{ppm}$. The initially applied reduced electric field between the gap, $(\mathrm{E} / \mathrm{N})_{0}$, given by $(\mathrm{E} / \mathrm{N})_{0}=$ $\mathrm{V}_{0} /(\mathrm{d} . \mathrm{N})$ where $\mathrm{N}$ is the total density of the gas mixture and d is the electrode gap, is fixed to $200 \mathrm{Td}$ $\left(\mathrm{V}_{0}=23 \mathrm{kV}\right)$. The deposited energy in the discharge, $\mathrm{E}_{\mathrm{D}}$, is chosen constant and equal to $4.6 \mathrm{~J}$, which gives a specific energy, $E_{S D}=E_{D} / V_{D}$, equal to $92 \mathrm{~J} / 1$ per current pulse. A gas compressor is used to produce a gas flow through the discharge gap $(1 \mathrm{~cm})$. The discharge frequency, $1.25 \mathrm{~Hz}$, is chosen 
such that the whole reactor volume, $500 \mathrm{~cm}^{3}$, is renewed between two discharges. The volume of the experimental device, $\mathrm{V}_{\mathrm{T}}=9$ litres, which corresponds to the total volume of the gas mixture studied, is much higher than the discharge one (volume ratio equal to 180) owing to the use of a tank in the loop. We also define the specific energy, $E_{S T}$, deposited in the whole device volume by $E_{S T}=\varepsilon E_{D} / V_{T}$, where $\varepsilon$ is the number of discharges in this mixture at a repetition frequency of $1.25 \mathrm{~Hz}$.

\section{Chromatographic measurements}

The concentration value of propane and of its by-products was monitored using chromatographic techniques. For a given mixture composition, a gas mixture sample is pumped in a syringe and introduced either in a FID chromatograph (ThermoQuest Trace GC equipped with a Varian CP Porabond Q column, $25 \mathrm{~m} \times 0.25 \mathrm{~mm} \times 3 \mu \mathrm{m}$ ) or in a CP 4900 Micro Gaschromatograph (Varian) with a TCD detector using two channels : CP-Sil 5 CB column for analysis of hydrocarbons and Molsieve $5 \AA$ column for analysis of hydrogen.

The decrease of the propane concentration, $\left[\mathrm{C}_{3} \mathrm{H}_{8}\right]$, was measured in the whole device volume, $\mathrm{V}_{\mathrm{T}}$, as function of the number of discharges, $\varepsilon$, performed in the $\mathrm{N}_{2} / \mathrm{C}_{3} \mathrm{H}_{8}$ mixture for different values of the initial hydrocarbon concentration, $\left[\mathrm{C}_{3} \mathrm{H}_{8}\right]_{0}$. In figure 1 is plotted the result obtained for $\left[\mathrm{C}_{3} \mathrm{H}_{8}\right]_{0}$ equal to $5130 \mathrm{ppm}$.

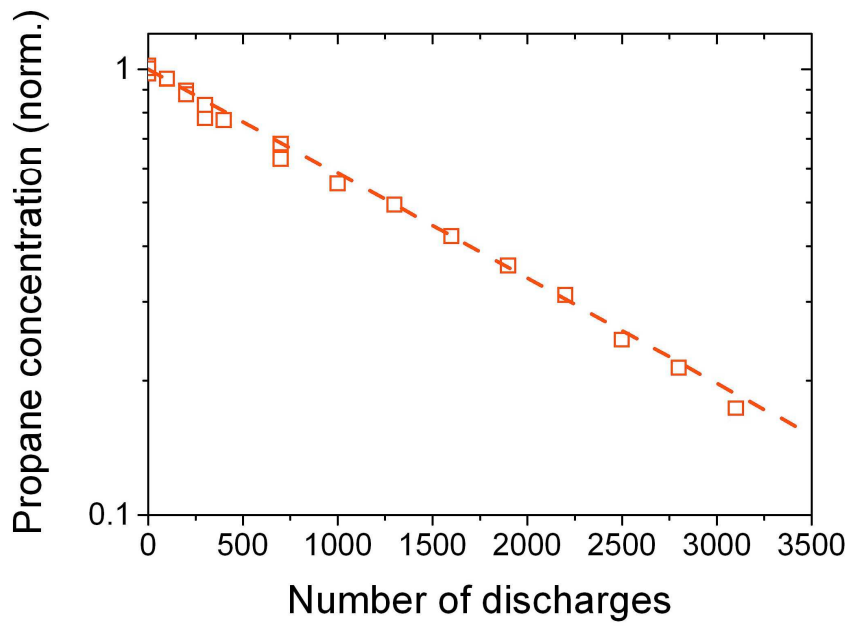

Figure 1. Normalised propane concentration measured in the whole experimental device volume for a mixture with $5000 \mathrm{ppm}$ of hydrocarbon.

It appears that, for all initial concentration values studied, $\left[\mathrm{C}_{3} \mathrm{H}_{8}\right]$ follows a single exponential law,

$$
\left[\mathrm{C}_{3} \mathrm{H}_{8}\right]=\left[\mathrm{C}_{3} \mathrm{H}_{8}\right]_{0} \exp \left(-\varepsilon / \varepsilon_{\mathrm{C}}\right)
$$

where $\varepsilon_{\mathrm{C}}$ can be understood as a characteristic number of discharges. This law can be written as,

$$
\left[\mathrm{C}_{3} \mathrm{H}_{8}\right]=\left[\mathrm{C}_{3} \mathrm{H}_{8}\right]_{0} \exp \left[-\mathrm{E}_{\mathrm{ST}} / \mathrm{E}_{\mathrm{C}}\right]
$$

where $E_{C}$ is a specific characteristic energy. Such a law has been also established for ethane [24] and acetaldehyde [27] using the same photo-triggered reactor, but in mixtures containing oxygen. We found here very similar results than those obtained for the removal of various VOCs by filamentary discharges (DBD or corona) in dry or wet air [28, 29]. It has been explained by some authors using a simplified global kinetic model [29]. The exponential law equivalent to (eq.2) can be obtained when a linear termination reaction is the dominant process for the radical, $\mathrm{R}$, responsible for the conversion of the pollutant molecule,

$$
\mathrm{R}+\mathrm{BG} \rightarrow \text { products }
$$

where BG is a molecule of the background gases. However, instead of one type of highly reactive specie R (i.e. the oxygen atom for mixtures with $\mathrm{O}_{2}$ ), the removal of a particular VOC is more likely 
due to more than one kinetic process, involving different types of radicals $(\mathrm{O}, \mathrm{OH}, \ldots)$ or even various molecular excited states (in particular in the $\mathrm{N}_{2}$ plasma). Using a DBD reactor, we obtained recently the same type of law than (eq.2) (at the lowest deposited energy values studied) in case of formaldehyde or toluene diluted in nitrogen [30,31]. Kinetic discussions below emphasise that $\mathrm{N}_{2}$ metastable states play a very important role for the conversion of propane by a photo-triggered discharge in the $\mathrm{N}_{2} / \mathrm{C}_{3} \mathrm{H}_{8}$ mixture.

Various molecules were issued from the removal of propane and detected by chromatography : $\mathrm{H}_{2}$, $\mathrm{HCN}, \mathrm{CH}_{4}, \mathrm{C}_{2} \mathrm{H}_{6}, \mathrm{C}_{3} \mathrm{H}_{6}$, and also $\mathrm{C}_{2} \mathrm{H}_{2}$ and $\mathrm{C}_{2} \mathrm{H}_{4}$ but these two hydrocarbons were not separated on chromatographs. Other small peaks were also observed, corresponding to unidentified species.

The main molecules $\left(\mathrm{H}_{2}, \mathrm{CH}_{4}, \mathrm{C}_{2} \mathrm{H}_{6}, \mathrm{C}_{3} \mathrm{H}_{6}\right.$, and the group $\mathrm{C}_{2} \mathrm{H}_{2}$ plus $\left.\mathrm{C}_{2} \mathrm{H}_{4}\right)$ were quantified after adequate calibration of apparatus. Quantification was not done for $\mathrm{HCN}$, but one peak on chromatograms can be unambiguously attributed to this compound by comparison with data obtained in various studies. Indeed, we have previously detected HCN by infra-red spectroscopy (FTIR) during treatment of hydrocarbons (ethane, toluene) and of VOCs (formaldehyde) in nitrogen by different types of discharges, DBD or photo-triggered [31-33], helping to the identification of the cyanic acid by GC-FID for the present experiment. However it was not possible to perform FTIR measurement on the UV510 reactor.

For example, the measured concentrations of methane, ethane, and propene in the whole device volume are plotted in figure 2 (in ppmC; a concentration of $100 \mathrm{ppm}$ of a molecule containing $\alpha$ carbon atoms corresponds to $\alpha .100 \mathrm{ppmC}$ ) for $\left[\mathrm{C}_{3} \mathrm{H}_{8}\right]_{0}=5000 \mathrm{ppm}$. All concentrations increase linearly when the number of discharges increases (dashed lines in figure 2), up to a value for which the treatment of molecules by the discharge leads to reduce the increase rates, or even leads to a decrease of concentrations. This effect is the more pronounced for unsaturated hydrocarbons like propene, but it occurs also for saturated ones. For conditions of figure 3, the maximum discharge number before treatment of products (limit for the linear increase of the concentration, spotted by arrows in figure 2) is 1200 for $\mathrm{CH}_{4}, 700$ for $\mathrm{C}_{2} \mathrm{H}_{6}$, and 200 for $\mathrm{C}_{3} \mathrm{H}_{6}$.

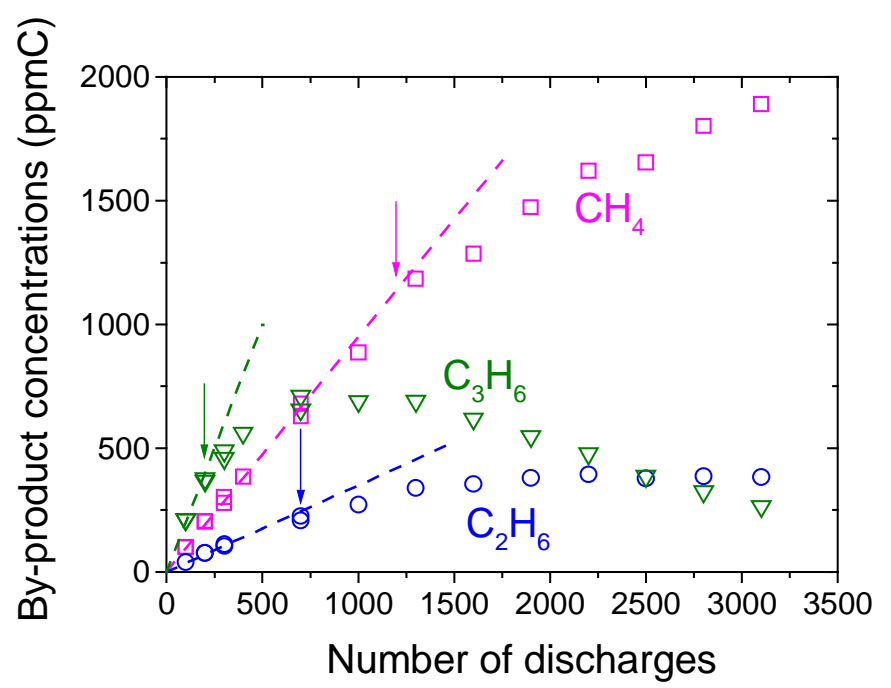

Figure 2. Concentrations of some by-products (in ppmC) measured in the whole experimental device volume for a mixture with $5000 \mathrm{ppm}$ of propane.

The propane concentration removed in the discharge volume $\mathrm{V}_{\mathrm{D}}\left(50 \mathrm{~cm}^{3}\right),\left[\mathrm{C}_{3} \mathrm{H}_{8}\right]_{\mathrm{D}}$, for one current pulse $(\varepsilon=1)$ can be straightforward determined. It is given by,

$$
\left[\mathrm{C}_{3} \mathrm{H}_{8}\right]_{\mathrm{D}}=\left[\mathrm{C}_{3} \mathrm{H}_{8}\right]_{0} \cdot\left[1-\exp \left(-1 / \varepsilon_{\mathrm{C}}\right)\right] \cdot \mathrm{V}_{\mathrm{T}} / \mathrm{V}_{\mathrm{D}}
$$

whereas for each by-product, the concentration produced in the discharge volume for one current pulse is simply given by,

$$
[\text { by-product }]=\eta \cdot V_{\mathrm{T}} / \mathrm{V}_{\mathrm{D}}
$$


where $\eta$ is the slope of the linear increase of concentration measured in $\mathrm{V}_{\mathrm{T}}$ at low discharge numbers. In table 1 are given the range of concentration values measured for each species. It emphasises that hydrogen is the most populated product, followed by methane, and thereafter heavier hydrocarbons. Amongst them, propene is the most populated.

Table 1. Concentration of products measured, for one current pulse, in the discharge volume.

\begin{tabular}{ccc}
\hline Molecule & $\begin{array}{c}\text { Minimum } \\
\text { concentration } \\
(\mathrm{ppm})\end{array}$ & $\begin{array}{c}\text { Maximum } \\
\text { concentration } \\
(\mathrm{ppm})\end{array}$ \\
\hline Hydrogen & 180 & 400 \\
Methane & 10 & 150 \\
Acetylene + Ethene & 10 & 70 \\
Ethane & 3 & 35 \\
Propene & 4 & 110
\end{tabular}

The interpretation of these measurements needs to develop a kinetic model with adequate description of each compound reactivity, gain and loss processes. This is the subject of the following part.

\section{Kinetic analysis}

\subsection{Self-consistent modelling}

Experimental results were compared to predictions of a self-consistent 0D modelling of the discharge and of the plasma kinetic. This model couples : (i) the solution of the Boltzmann equation for the electrons, (ii) the kinetic equations describing the temporal evolution of the various species (molecular excited states, ions, atoms, radicals, molecules) produced during the discharge or during the afterglow, and, (iii) the electric circuit equations given by the Kirchoff laws. The gas temperature time evolution is taken into account through the resolution of the energy conservation equation. The model has been described in detail previously, together with the kinetic scheme adopted for the nitrogen molecule [21, $23,34]$. For this molecule, the excited species correspond to effective states clustering real molecular levels. Details about molecular excited states and cross sections taken into account are given in [35, 36], and references therein. Data on propane are from [15]. The kinetic of the mixture includes electron collisions on molecules, negative and positive ions reactions (recombination and charge transfers), collisions of ions with neutrals, Penning collisions, $\mathrm{v}-\mathrm{v}$ and $\mathrm{v}-\mathrm{T}$ processes of $\mathrm{N}_{2}$, radiative de-excitation and quenching processes of excited states, excitation transfers, radical and molecule reactions. Coefficients for electron collisions are directly obtained from the solution of the Boltzmann equation, while those for reactions between the heavy species (neutrals and ions) are taken in great part from a critical review of various compilations and from databases [37-42].

In Appendix $\mathrm{A}$ are listed ions and neutral species taken into account in the full kinetic model developed for the $\mathrm{N}_{2} / \mathrm{C}_{3} \mathrm{H}_{8}$ mixture (except nitrogen molecular excited states, see [23]). Appendix B and $\mathrm{C}$, together with other tables in the main text, give the list of processes for ions and for neutral species given in appendix A (carbonated compounds). In table 2 are given dissociation reactions for propane and for its by-products, involving the metastable states of nitrogen; other reactions taken into account for these particular states are listed in table 3. Table 4 gives the most important reactions (not recalled in appendix $C$ ) for the species which concentration values were measured. These set of reactions were determined following computations using the full kinetic scheme for the whole range of initial propane concentration experimentally studied. Processes listed in appendix $\mathrm{C}$ were also employed in order to estimate, by the model, the carbon atom distribution following the electrical excitation of the $\mathrm{N}_{2} / \mathrm{C}_{3} \mathrm{H}_{8}$ mixture (see section 5.2). 
Table 2. Quenching collisions of the nitrogen metastable states on propane, propene, ethane, ethene, acetylene, methane, and hydrogen. Numbers in parentheses in the left column refer to a citation in the text. Reaction coefficients are given by the Arrhénius function : $\mathrm{K}=\mathrm{A} \mathrm{T}_{\mathrm{g}}{ }^{\mathrm{n}} \exp \left(-\mathrm{E} /\left(\mathrm{RT}_{\mathrm{g}}\right)\right)$ where $\mathrm{T}_{\mathrm{g}}$ is the gas mixture temperature (in $\mathrm{K}$ ). $\mathrm{A}$ is given in units of $\mathrm{cm}^{3} \mathrm{~s}^{-1}$.

\begin{tabular}{|c|c|c|c|c|c|}
\hline & & A & $\mathrm{n}$ & $-\mathrm{E} / \mathrm{R}$ & Ref. \\
\hline \multicolumn{6}{|c|}{ Propane dissociation } \\
\hline (6) : & $\mathrm{N}_{2}\left(\mathrm{~A}^{3} \Sigma_{\mathrm{u}}^{+}\right)+\mathrm{C}_{3} \mathrm{H}_{8} \rightarrow \mathrm{C}_{3} \mathrm{H}_{6}+\mathrm{H}_{2}+\mathrm{N}_{2}$ & $1.3(-12)$ & 0 & 0 & $\begin{array}{l}{[19,20]} \\
\text { this work }\end{array}$ \\
\hline (7) : & $\mathrm{N}_{2}\left(\mathrm{a}^{\prime}\right)+\mathrm{C}_{3} \mathrm{H}_{8} \rightarrow \mathrm{C}_{3} \mathrm{H}_{6}+\mathrm{H}_{2}+\mathrm{N}_{2}$ & $3.0(-10)$ & 0 & 0 & this work \\
\hline \multicolumn{6}{|c|}{ Propene dissociation (case $\mathrm{A}$ in figures 5 and 6, agreement with experimental results) } \\
\hline$(12)$ & $\mathrm{N}_{2}\left(\mathrm{~A}^{3} \Sigma_{\mathrm{u}}^{+}\right)+\mathrm{C}_{3} \mathrm{H}_{6} \rightarrow \mathrm{CH}_{2}=\mathrm{CHCH}_{2}+\mathrm{H}+\mathrm{N}_{2}$ & $1.4(-10)$ & 0 & 0 & $\begin{array}{l}{[20,43]} \\
\text { this work }\end{array}$ \\
\hline$(13)$ & $\mathrm{N}_{2}\left(\mathrm{a}^{\prime}\right)+\mathrm{C}_{3} \mathrm{H}_{6} \rightarrow \mathrm{CH}_{2}=\mathrm{CHCH}_{2}+\mathrm{H}+\mathrm{N}_{2}$ & $1.4(-10)$ & 0 & 0 & this work \\
\hline$(14)$ & $\mathrm{N}_{2}\left(\mathrm{~A}^{3} \Sigma^{+}{ }_{\mathrm{u}}\right)+\mathrm{C}_{3} \mathrm{H}_{6} \rightarrow \mathrm{C}_{2} \mathrm{H}_{3}+\mathrm{CH}_{3}+\mathrm{N}_{2}$ & $1.4(-10)$ & 0 & 0 & $\begin{array}{l}{[20,43]} \\
\text { this work }\end{array}$ \\
\hline$(15)$ & $\mathrm{N}_{2}\left(\mathrm{a}^{\prime}\right)+\mathrm{C}_{3} \mathrm{H}_{6} \rightarrow \mathrm{C}_{2} \mathrm{H}_{3}+\mathrm{CH}_{3}+\mathrm{N}_{2}$ & $1.4(-10)$ & 0 & 0 & this work \\
\hline
\end{tabular}

Propene dissociation (case $\mathrm{B}$ in figures 5 and 6 , alternative dissociation process, see text)
(16) : $\mathrm{N}_{2}\left(\mathrm{a}^{\prime}\right)+\mathrm{C}_{3} \mathrm{H}_{6} \rightarrow \mathrm{C}_{2} \mathrm{H}_{4}+\mathrm{CH}_{2}+\mathrm{N}_{2}$
$2.8(-10)$
0
this work
Ethane dissociation
R3: $\quad \mathrm{N}_{2}\left(\mathrm{~A}^{3} \Sigma_{\mathrm{u}}^{+}\right)+\mathrm{C}_{2} \mathrm{H}_{6} \rightarrow \mathrm{C}_{2} \mathrm{H}_{4}+\mathrm{H}_{2}+\mathrm{N}_{2}$
$1.8(-10)$
$0 \quad-1980$
R4: $\quad \mathrm{N}_{2}\left(\mathrm{a}^{\prime}\right)+\mathrm{C}_{2} \mathrm{H}_{6} \rightarrow \mathrm{C}_{2} \mathrm{H}_{4}+\mathrm{H}_{2}+\mathrm{N}_{2}$
$5.0(-8)$
$-1980$

Ethene dissociation

$\begin{array}{lllll}\text { R5 : } & \mathrm{N}_{2}\left(\mathrm{~A}^{3} \Sigma^{+}{ }_{\mathrm{u}}\right)+\mathrm{C}_{2} \mathrm{H}_{4} \rightarrow \mathrm{C}_{2} \mathrm{H}_{3}+\mathrm{H}+\mathrm{N}_{2} & 5.5(-11) & 0 & 0 \\ \text { R6 : } & \mathrm{N}_{2}\left(\mathrm{a}^{\prime}\right)+\mathrm{C}_{2} \mathrm{H}_{4} \rightarrow \mathrm{C}_{2} \mathrm{H}_{3}+\mathrm{H}+\mathrm{N}_{2} & 2.0(-10) & 0 & 0 \\ \text { R7 : } & \mathrm{N}_{2}\left(\mathrm{~A}^{3} \Sigma^{+}{ }_{\mathrm{u}}\right)+\mathrm{C}_{2} \mathrm{H}_{4} \rightarrow \mathrm{C}_{2} \mathrm{H}_{2}+\mathrm{H}_{2}+\mathrm{N}_{2} & 5.5(-11) & 0 & 0 \\ \text { R8 : } & \mathrm{N}_{2}\left(\mathrm{a}^{\prime}\right)+\mathrm{C}_{2} \mathrm{H}_{4} \rightarrow \mathrm{C}_{2} \mathrm{H}_{2}+\mathrm{H}_{2}+\mathrm{N}_{2} & 2.0(-10) & 0 & 0\end{array}$

Acetylene dissociation
R9: $\quad \mathrm{N}_{2}\left(\mathrm{~A}^{3} \Sigma^{+}{ }_{\mathrm{u}}\right)+\mathrm{C}_{2} \mathrm{H}_{2} \rightarrow \mathrm{C}_{2} \mathrm{H}+\mathrm{H}+\mathrm{N}_{2}$
$2.0(-10)$
0
0
R10 : $\mathrm{N}_{2}\left(\mathrm{a}^{\prime}\right)+\mathrm{C}_{2} \mathrm{H}_{2} \rightarrow \mathrm{C}_{2} \mathrm{H}+\mathrm{H}+\mathrm{N}_{2}$
$3.0(-10)$
0
0
estimated

Methane dissociation
R11: $\mathrm{N}_{2}\left(\mathrm{~A}^{3} \Sigma^{+}{ }_{\mathrm{u}}\right)+\mathrm{CH}_{4} \rightarrow \mathrm{CH}_{3}+\mathrm{H}+\mathrm{N}_{2}$
$1.2(-10)$
0
$-3170$
R12: $\mathrm{N}_{2}\left(\mathrm{a}^{\prime}\right)+\mathrm{CH}_{4} \rightarrow \mathrm{CH}_{3}+\mathrm{H}+\mathrm{N}_{2}$
$3.0(-10)$
0

[20]

[25]

Hydrogen dissociation
(8): $\quad \mathrm{N}_{2}\left(\mathrm{~A}^{3} \Sigma^{+}{ }_{\mathrm{u}}\right)+\mathrm{H}_{2} \rightarrow \mathrm{H}+\mathrm{H}+\mathrm{N}_{2}$
(9) : $\quad \mathrm{N}_{2}\left(\mathrm{a}^{\prime}\right)+\mathrm{H}_{2} \rightarrow \mathrm{H}+\mathrm{H}+\mathrm{N}_{2}$

$4.4(-10)$

0

$-3500$

$2.6(-11)$

0 


\subsection{The photo-triggered discharge in pure nitrogen}

In figure 3 are plotted the predicted time evolutions of the electron density, the $\mathrm{N}$-atom density, and the densities of nitrogen excited states, for the conditions of the experiment.

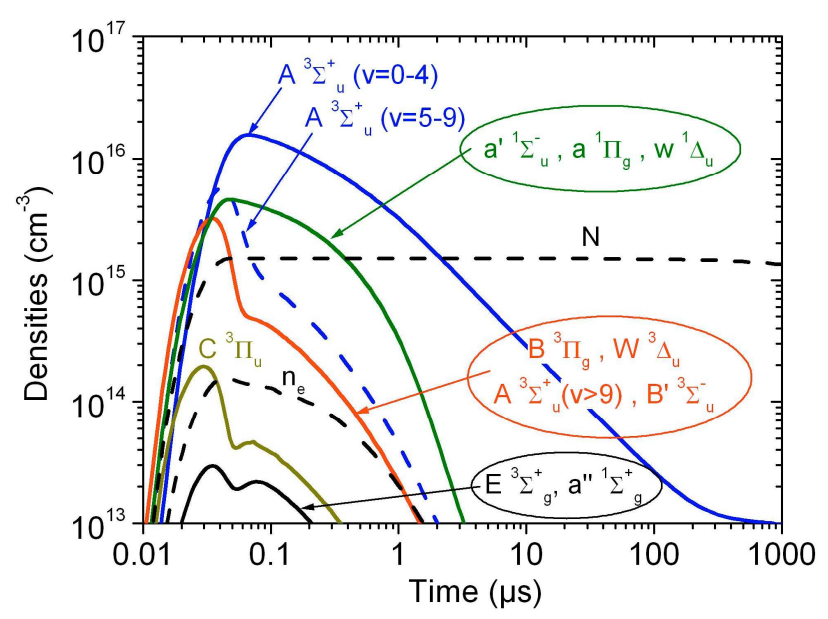

Figure 3. Predicted time evolutions of species created by the UV510 photo-triggered discharge in nitrogen, for a pressure of 460 mbars and an applied voltage of $23 \mathrm{kV}$.

The maximum electron density is $1.57 \times 10^{14} \mathrm{~cm}^{-3}$, and the most populated $\mathrm{N}_{2}$ states are metastables except at the very beginning of the current pulse. In the table 3 are given the production and loss reactions taken into account for these states (apart from electron collisions : excitation and super elastic ones), together with their coefficient. In this table, $\mathrm{N}_{2}(\mathrm{~B})$ denotes the group of states : $\mathrm{B}^{3} \Pi_{\mathrm{g}}, \mathrm{W}$ ${ }^{3} \Delta_{\mathrm{u}}, \mathrm{B}^{\prime}{ }^{3} \Sigma_{\mathrm{u}}^{-}$, together with the high vibrational levels of $\mathrm{A}^{3} \Sigma^{+}{ }_{\mathrm{u}}, \mathrm{v}>9, N_{2}(\mathrm{C})$ is the $\mathrm{C}^{3} \Pi_{\mathrm{u}}$ state, $N_{2}(\mathrm{E})$ is the group : $\mathrm{E}^{3} \Sigma_{\mathrm{g}}^{+}$together with a" ${ }^{1} \Sigma_{\mathrm{g}}^{+}$, and $\mathrm{N}_{2}\left(\mathrm{a}^{\prime}\right)$ denotes the group of singlets : a' ${ }^{1} \Sigma_{\mathrm{u}}^{-}, \mathrm{a}{ }^{1} \Pi_{\mathrm{g}}$, and $\mathrm{w}$ ${ }^{1} \Delta_{\mathrm{u}}[21,23,34-36]$. 
Table 3. Reactions for the nitrogen metastable states in the nitrogen plasma. Reaction coefficients are given by the function :

$\mathrm{K}=\mathrm{A} \exp \left(-\mathrm{E} /\left(\mathrm{RT} \mathrm{T}_{\mathrm{g}}\right)\right)$ where $\mathrm{T}_{\mathrm{g}}$ is the gas mixture temperature (in $\left.\mathrm{K}\right)$.

$\mathrm{A}$ is given in units of $\mathrm{s}^{-1}$ (radiative decay), $\mathrm{cm}^{3} \mathrm{~s}^{-1}$ (two body collisions), or $\mathrm{cm}^{6} \mathrm{~s}^{-1}$ (three body collisions).

\begin{tabular}{|c|c|c|c|}
\hline & Reaction & A & $-\mathrm{E} / \mathrm{R}$ \\
\hline R1: & $\mathrm{N}+\mathrm{N}+\mathrm{N}_{2} \rightarrow \mathrm{N}_{2}\left(\mathrm{~A}^{3} \Sigma_{\mathrm{u}}^{+}, \mathrm{v}=0-4\right)+\mathrm{N}_{2}$ & $1.38(-34)$ & 500 \\
\hline R2: & $\mathrm{N}+\mathrm{N}+\mathrm{N}_{2} \rightarrow \mathrm{N}_{2}\left(\mathrm{~A}^{3} \Sigma_{\mathrm{u}}^{+}, \mathrm{v}=5-9\right)+\mathrm{N}_{2}$ & $1.38(-34)$ & 500 \\
\hline R3 : & $\mathrm{N}_{2}\left(\mathrm{~A}^{3} \Sigma_{\mathrm{u}}^{+}, \mathrm{v}=5-9\right)+\mathrm{N}_{2} \rightarrow \mathrm{N}_{2}\left(\mathrm{~A}^{3} \Sigma_{\mathrm{u}}^{+}, \mathrm{v}=0-4\right)+\mathrm{N}_{2}$ & $1.0(-11)$ & 0 \\
\hline R4 : & $\mathrm{N}_{2}\left(\mathrm{~A}^{3} \Sigma_{\mathrm{u}}^{+}, \mathrm{v}=0-4\right)+\mathrm{N}_{2} \rightarrow \mathrm{N}_{2}+\mathrm{N}_{2}$ & $3.0(-16)$ & 0 \\
\hline R5 : & $\mathrm{N}_{2}\left(\mathrm{~A}^{3} \Sigma_{\mathrm{u}}^{+}, \mathrm{v}=5-9\right)+\mathrm{N}_{2} \rightarrow \mathrm{N}_{2}+\mathrm{N}_{2}$ & $3.0(-16)$ & 0 \\
\hline R6 : & $\mathrm{N}_{2}\left(\mathrm{~A}^{3} \Sigma_{\mathrm{u}}^{+}, \mathrm{v}=0-4\right)+\mathrm{N}_{2}\left(\mathrm{~A}^{3} \Sigma_{\mathrm{u}}^{+}, \mathrm{v}=0-4\right) \rightarrow \mathrm{N}_{2}(\mathrm{~B})+\mathrm{N}_{2}$ & $2.0(-10)$ & 0 \\
\hline R7 : & $\mathrm{N}_{2}\left(\mathrm{~A}^{3} \Sigma^{+}{ }_{\mathrm{u}}, \mathrm{v}=0-4\right)+\mathrm{N}_{2}\left(\mathrm{~A}^{3} \Sigma^{+}{ }_{\mathrm{u}}, \mathrm{v}=0-4\right) \rightarrow \mathrm{N}_{2}(\mathrm{C})+\mathrm{N}_{2}$ & $1.5(-10)$ & 0 \\
\hline R8 : & $\mathrm{N}_{2}\left(\mathrm{~A}^{3} \Sigma^{+}{ }_{\mathrm{u}}, \mathrm{v}=0-4\right)+\mathrm{N}_{2}\left(\mathrm{~A}^{3} \Sigma^{+}{ }_{\mathrm{u}}, \mathrm{v}=0-4\right) \rightarrow \mathrm{N}_{2}(\mathrm{E})+\mathrm{N}_{2}$ & $1.0(-11)$ & 0 \\
\hline R9 : & $\mathrm{N}_{2}(\mathrm{~B}) \rightarrow \mathrm{N}_{2}\left(\mathrm{~A}^{3} \Sigma_{\mathrm{u}}^{+}, \mathrm{v}=0-4\right)$ & $1.1(5)$ & 0 \\
\hline R10 : & $\mathrm{N}_{2}(\mathrm{~B})+\mathrm{N}_{2} \rightarrow \mathrm{N}_{2}\left(\mathrm{~A}^{3} \Sigma^{+}{ }_{\mathrm{u}}, \mathrm{v}=5-9\right)+\mathrm{N}_{2}$ & $2.0(-11)$ & 0 \\
\hline R11 : & $\mathrm{N}_{2}\left(\mathrm{a}^{\prime}\right)+\mathrm{N}_{2} \rightarrow \mathrm{N}_{2}(\mathrm{~B})+\mathrm{N}_{2}$ & $2.3(-13)$ & 0 \\
\hline R12 : & $\mathrm{N}_{2}(\mathrm{C}) \rightarrow \mathrm{N}_{2}(\mathrm{~B})$ & $2.8(7)$ & 0 \\
\hline R13 : & $\mathrm{N}_{2}(\mathrm{C})+\mathrm{N}_{2} \rightarrow \mathrm{N}_{2}(\mathrm{~B})+\mathrm{N}_{2}$ & $8.2(-11)$ & 0 \\
\hline R14 : & $\mathrm{N}_{2}(\mathrm{C})+\mathrm{N}_{2} \rightarrow \mathrm{N}_{2}\left(\mathrm{a}^{\prime}\right)+\mathrm{N}_{2}$ & $1.0(-11)$ & 0 \\
\hline R15 & $\mathrm{N}_{2}(\mathrm{E})+\mathrm{N}_{2} \rightarrow \mathrm{N}_{2}(\mathrm{C})+\mathrm{N}_{2}$ & $1.0(-11)$ & 0 \\
\hline R16 : & $\mathrm{N}_{2}\left(\mathrm{a}^{\prime}\right)+\mathrm{N}_{2}\left(\mathrm{~A}^{3} \Sigma^{+}{ }_{\mathrm{u}}, \mathrm{v}=0-4\right) \rightarrow \mathrm{N}_{4}^{+}+\mathrm{e}^{-}$ & $5.0(-11)$ & 0 \\
\hline R17 : & $\mathrm{N}_{2}\left(\mathrm{a}^{\prime}\right)+\mathrm{N}_{2}\left(\mathrm{~A}^{3} \Sigma_{\mathrm{u}}^{+}, \mathrm{v}=5-9\right) \rightarrow \mathrm{N}_{4}^{+}+\mathrm{e}^{-}$ & $5.0(-11)$ & 0 \\
\hline R18 : & $\mathrm{N}_{2}\left(\mathrm{a}^{\prime}\right)+\mathrm{N}_{2}\left(\mathrm{a}^{\prime}\right) \rightarrow \mathrm{N}_{4}^{+}+\mathrm{e}^{-}$ & $2.0(-10)$ & 0 \\
\hline
\end{tabular}

\subsection{Role of metastable states of nitrogen in the removal of propane}

A first step kinetic model for propane takes into account charge transfer reactions for the four main ions produced by electron ionisation collisions, $\mathrm{C}_{3} \mathrm{H}_{8}{ }^{+}, \mathrm{C}_{3} \mathrm{H}_{7}{ }^{+}, \mathrm{C}_{2} \mathrm{H}_{5}{ }^{+}$, and $\mathrm{C}_{2} \mathrm{H}_{4}{ }^{+}$, and reactions for the corresponding ionic by-products. The hydrocarbon can be also dissociated by electronic collisions producing neutral species,

$$
\mathrm{e}+\mathrm{C}_{3} \mathrm{H}_{8} \rightarrow \text { products }+\mathrm{e}
$$

where either optically forbidden (with an electron energy threshold at $3.6 \mathrm{eV}$ ) or allowed (threshold at $9.13 \mathrm{eV}$ ) transitions are involved [15]. For traces of propane diluted in nitrogen and for the reduced electric field of our experiment (maximum value of $200 \mathrm{Td}$ ), the allowed transitions play a minor role compared to the forbidden transitions owing to their higher threshold energy, although their maximum cross section value is higher. Moreover the dissociation of the molecule is more probable through forbidden transitions. Reaction (2) leads to various radicals and molecules : $\mathrm{H}, \mathrm{H}_{2}, \mathrm{CH}_{2}, \mathrm{CH}_{3}, \mathrm{CH}_{4}$, $\mathrm{C}_{2} \mathrm{H}_{4}, \mathrm{C}_{2} \mathrm{H}_{5}, \mathrm{C}_{2} \mathrm{H}_{6}, \mathrm{C}_{3} \mathrm{H}_{6}, \mathrm{C}_{3} \mathrm{H}_{7}$, following the excitation of anti-bounding excited states of propane, and bound states that quickly pre-dissociate [18]. In the first step, all these products (and their respective kinetics) were not taken into account in the model, in order to determine the role of reaction (2) as well as the role of the nitrogen ions (reactions B1-B7 in appendix B) in the removal of propane with respect to quenching processes of the most populated nitrogen excited states, i.e. the metastables,

$$
\mathrm{N}_{2}\left(\mathrm{~A}^{3} \Sigma^{+}{ }_{\mathrm{u}}\right)+\mathrm{C}_{3} \mathrm{H}_{8} \rightarrow \mathrm{C}_{3} \mathrm{H}_{8}{ }^{*}+\mathrm{N}_{2}
$$




$$
\mathrm{N}_{2}\left(\mathrm{a}^{\prime}\right)+\mathrm{C}_{3} \mathrm{H}_{8} \rightarrow \mathrm{C}_{3} \mathrm{H}_{8} *+\mathrm{N}_{2}
$$

followed by,

$$
\mathrm{C}_{3} \mathrm{H}_{8} * \rightarrow \text { products }
$$

This set of reactions is only suppositional, because no data exists in the literature about exit pathways for collisions between nitrogen states and propane. Writing of reaction (5) follows from the comparison between our experimental results and kinetic model predictions. It is discussed in more detail thereafter. $\mathrm{C}_{3} \mathrm{H}_{8} *$ denotes an electronically excited state (or a group of states) with an energy lower than $6.17 \mathrm{eV}$ (energy of the $\mathrm{v}=0$ level of $\mathrm{A}^{3} \Sigma^{+}$) or slightly above. It should be a triplet [45-48] and it should also be created by electron collisions included in the group of optically forbidden transitions (maximum excitation cross section at $6.1 \mathrm{eV} \mathrm{[15]).} \mathrm{We} \mathrm{suppose} \mathrm{that} \mathrm{it} \mathrm{dissociates} \mathrm{in} \mathrm{times}$ short as compared to those required for internal vibrational energy redistribution, so that the propane molecule is effectively lost through reactions (3) and (4).

The figure 4 presents the propane concentration removed in the discharge volume per current pulse, as function of the initial concentration in the $\mathrm{N}_{2} / \mathrm{C}_{3} \mathrm{H}_{8}$ mixture. Symbols are for experimental results, and lines correspond to model predictions according to different kinetic schemes (only concerning $\mathrm{C}_{3} \mathrm{H}_{8}$, all reactions relevant for the nitrogen plasma being taken into account) as described below :

- case 1 : only electron collisions (line 1a), reaction (2), or these collisions together with the ions kinetic (line 1b, see appendix B) are taken into account ;

- case 2 (line 2) : quenching processes of $\mathrm{N}_{2}\left(\mathrm{~A}^{3} \Sigma^{+}{ }_{\mathrm{u}}\right)$ and $\mathrm{N}_{2}\left(\mathrm{a}^{\prime}\right)$ by the propane molecule are added, reactions (3) and (4), with the rate constant value $\mathrm{k}_{3}=\mathrm{k}_{4}=1.3 \times 10^{-12} \mathrm{~cm}^{3} \mathrm{~s}^{-1}$, previously determined by Callear and Wood for the $\mathrm{A}^{3} \Sigma^{+}{ }_{\mathrm{u}}$ state [19] ;

- case 3 (line 3) : the rate constant for the $\mathrm{N}_{2}\left(a^{\prime}\right)$ quenching is increased by about two orders of magnitude, i.e. $1.25 \times 10^{-10} \mathrm{~cm}^{3} \mathrm{~s}^{-1}$, in order to fit experimental points.

For all these three cases, no reaction is included for the dissociation products coming from propane. The constant $\mathrm{k}_{4}$ was also estimated using the full kinetic scheme, i.e. taken into account all dissociation processes, as well as conversion (reactions C12-C17) and production (reactions C19-C27, and $\mathrm{R} 22$ in table 5) processes of $\mathrm{C}_{3} \mathrm{H}_{8}$ through interactions between neutral species. It gives

$\mathrm{k}_{4}=3.0 \times 10^{-10} \mathrm{~cm}^{3} \mathrm{~s}^{-1}$; predictions obtained using this constant value, plotted as dashed line 4 in figure 4 , are very close to line 3 .

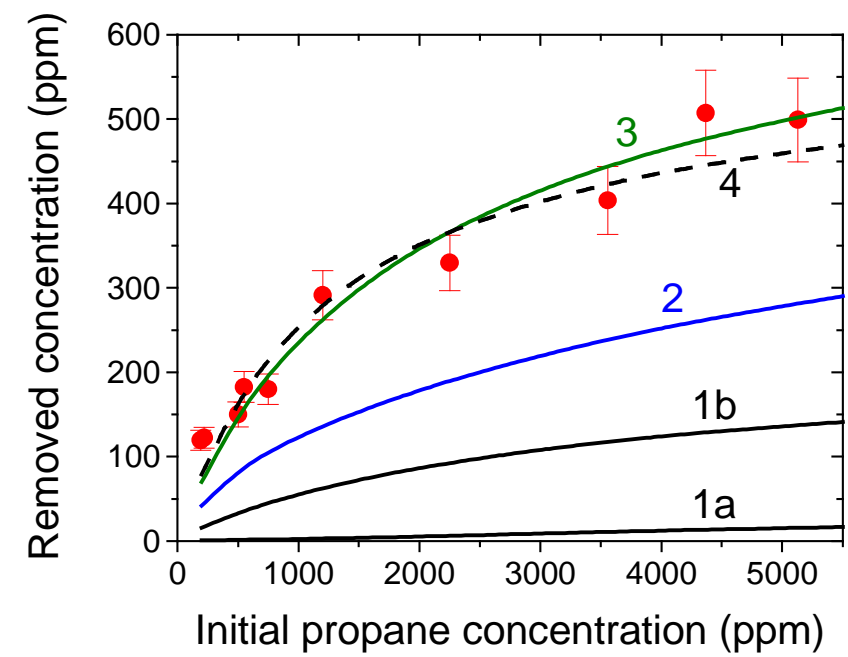

Figure 4. Propane concentration removed per current pulse in the discharge volume of the UV510 reactor. Full lines : model predictions for simplified kinetic schemes, see text. Dashed line : model predictions for the full kinetic scheme.

As already written above, we suppose that quenching collisions of the nitrogen metastable states with propane leads only to the dissociation of the hydrocarbon molecule. This assumption deserves to be discussed with respect to the available literature on the subject. For the $\mathrm{A}^{3} \Sigma^{+}{ }_{\mathrm{u}}$ state, Golde [46] argued there is only one mechanism for quenching, electronic to electronic energy transfer to an excited state of the collision partner, which can then decompose. Later Herron [40] discussed this 
process in a review, and recalled that the dissociation reaction may be dependent on the acceptor species. In fact the dissociation of the collision partner with $\mathrm{N}_{2}\left(\mathrm{~A}^{3} \Sigma^{+}{ }_{\mathrm{u}}\right)$ has been observed for several molecules and it has been measured to be the dominant channel for numerous compounds [40, 43-48]. About hydrocarbons, Meyer et al. [43] have previously suggested that the decomposition of $\mathrm{C}_{2} \mathrm{H}_{4}$ and cis- $\mathrm{C}_{4} \mathrm{H}_{8}$ follows the creation of an electronically excited triplet state of the olefin. Unfortunately there is no published work about propane. There is no product data for most alkanes, but many studies have been performed on methane [40] and the hydrogen atom has been detected as a product [48]. It can be also noticed that the hydrocarbon dissociation has been widely invoked in non-thermal plasma modelling to support experimental studies on methane conversion by different types of discharges in $\mathrm{N}_{2} / \mathrm{CH}_{4}$ mixtures [49-52].

Clearly the predictions corresponding to cases 1 and 2 in figure 4 differ strongly from measurement results. The disagreement for the case 2 should be more pronounced if one consider that the quenching processes of the $\mathrm{N}_{2}$ states are in part non dissociative. Otherwise the coefficient previously determined for $A^{3} \Sigma^{+}{ }_{u}$ [19] must be increased in order to fit our experimental points. We choose not to do that because a good agreement can be achieved if only the constant for the $\mathrm{N}_{2}\left(\mathrm{a}^{\prime}\right)$ quenching is increased, cases 3 and 4. Looking at the literature, it must be pointed out that the higher rate constant for the quenching of singlets than for $\mathrm{A}^{3} \Sigma^{+} \mathrm{u}$ has been previously demonstrated for methane [25], ethene [26], and ethane [24] (see also table 2). So, from our experimental data and modelling results, it seems that the measured removal of the propane molecule can not be explained without considering that $\mathrm{C}_{3} \mathrm{H}_{8}$ is effectively lost following the collision on $\mathrm{N}_{2}\left(\mathrm{~A}^{3} \Sigma^{+}{ }_{\mathrm{u}}\right)$ and on $\mathrm{N}_{2}\left(\mathrm{a}^{\prime}\right)$, i.e. considering that such a collision is a dissociation process. Predictions for case 1 largely underestimate the propane removal, demonstrating that neither the electronic collisions nor the ions kinetic can explain our measurement results on the $\mathrm{C}_{3} \mathrm{H}_{8}$ concentration. The only way to describe these results is to consider reactions (3) and (4) as purely dissociative processes, i.e. followed by (5). This approach is also consistent with results obtained about by-products, discussed in the following section. However the proposed dissociation pathways, and the estimated coefficient for the singlet states, should be understood more as primarily data rather than definitive ones. These data should be useful for the understanding of nonequilibrium plasmas in the $\mathrm{N}_{2} / \mathrm{C}_{3} \mathrm{H}_{8}$ mixture, but more dedicated experiments using other techniques making use of a less complex reactive medium are needed in order to explore in more details the collisional processes described by reactions (3) and (4). This remark is also valid for other $\mathrm{C}_{2}$ and $\mathrm{C}_{3}$ hydrocarbon molecules cited in table 2 .

\subsection{Propane dissociation products}

The table 4 gives the dissociation energies for the different bonds in the propane and in the propene molecules. Nitrogen metastable states have enough energy to induce the breaking of either C-C or C-H bonds in $\mathrm{C}_{3} \mathrm{H}_{8}$, as it can be seen by comparison of the states energy $\left(\mathrm{A}^{3} \Sigma^{+}{ }_{\mathrm{u}}: 6.17 \mathrm{eV}\right.$, singlets a' $: 8.4$ $\mathrm{eV}$ ) with the bounding energy values given in this table. 
Table 4. Bond energies in propane and ethene molecules, following calculations performed with the 6-311G(d,p) basic set and using the B3LYP theoretical method [53].

\begin{tabular}{|c|c|}
\hline Bond & Energy $(\mathrm{eV})$ \\
\hline \multicolumn{2}{|c|}{ Propane } \\
\hline $\mathrm{C}-\mathrm{H}\left(\mathrm{CH}_{3}\right.$ group $)$ & 4.325 \\
\hline $\mathrm{C}-\mathrm{H}\left(\mathrm{CH}_{2}\right.$ group $)$ & 4.134 \\
\hline $\mathrm{C}-\mathrm{C}$ & 3.6 \\
\hline \multicolumn{2}{|c|}{ Propene } \\
\hline $\mathrm{C}-\mathrm{H}\left(\mathrm{CH}_{3}\right.$ group $)$ & 3.657 \\
\hline $\mathrm{C}-\mathrm{H}\left(\mathrm{CH}_{2}\right.$ group $)$ & 4.731 \\
\hline $\mathrm{C}-\mathrm{H}$ (vinyl group carbon) & 4.532 \\
\hline $\mathrm{C}-\mathrm{C}$ & 4.160 \\
\hline $\mathrm{C}=\mathrm{C}$ & 7.266 \\
\hline
\end{tabular}

Therefore reactions (3-5) should produce various radicals such as $\mathrm{H}, \mathrm{CH}_{3}, \mathrm{C}_{2} \mathrm{H}_{5}, \mathrm{n}-\mathrm{C}_{3} \mathrm{H}_{7}$, iso- $\mathrm{C}_{3} \mathrm{H}_{7}$. However we have found that such dissociation pathways (only one atom or radical and the complementary specie) are unable to explain experimental results for both hydrogen and propene concentrations (within a factor less than 2), over the whole range of initial propane concentration studied. The results of the full kinetic scheme plotted in figure 4 were obtained assuming that the propane dissociation products are only hydrogen and propene molecules,

$$
\begin{aligned}
& \mathrm{N}_{2}\left(\mathrm{~A}^{3} \Sigma^{+}{ }_{\mathrm{u}}\right)+\mathrm{C}_{3} \mathrm{H}_{8} \rightarrow \mathrm{C}_{3} \mathrm{H}_{6}+\mathrm{H}_{2}+\mathrm{N}_{2} \\
& \mathrm{~N}_{2}\left(\mathrm{a}^{\prime}\right)+\mathrm{C}_{3} \mathrm{H}_{8} \rightarrow \mathrm{C}_{3} \mathrm{H}_{6}+\mathrm{H}_{2}+\mathrm{N}_{2}
\end{aligned}
$$

Thus the intermediate excited states $\mathrm{C}_{3} \mathrm{H}_{8}{ }^{*}$ should dissociate to produce two molecules instead of radicals. Such a process has been suggested to occur for ethane, and to a less extend, for ethene based on a comparison of experimental plasma results with modelling [24]. Moreover it is noteworthy that molecular hydrogen elimination from propane has been also found to be a significant channel for the VUV photo-dissociation of $\mathrm{C}_{3} \mathrm{H}_{8}$ at $157 \mathrm{~nm}(7.87 \mathrm{eV})$ [54], although this dissociation is assigned to excitation of electronic states with a higher energy value [55].

The quenching of $\mathrm{N}_{2}$ states by hydrogen is known and it has been taken into account in our model $[20,25]$, see table 2 ,

$$
\begin{aligned}
& \mathrm{N}_{2}\left(\mathrm{~A}^{3} \Sigma^{+}{ }_{\mathrm{u}}\right)+\mathrm{H}_{2} \rightarrow \mathrm{H}+\mathrm{H}+\mathrm{N}_{2} \\
& \mathrm{~N}_{2}\left(\mathrm{a}^{\prime}\right)+\mathrm{H}_{2} \rightarrow \mathrm{H}+\mathrm{H}+\mathrm{N}_{2}
\end{aligned}
$$

However there is little information in the literature about collisions of $\mathrm{N}_{2}\left(\mathrm{~A}^{3} \Sigma^{+}{ }_{\mathrm{u}}\right)$ with $\mathrm{C}_{3} \mathrm{H}_{6}[20,43]$ (only the rate constant value is known), but no data exists for the singlet states. Therefore we have assumed that the two following reactions have the same rate constant, $\mathrm{k}_{10}=\mathrm{k}_{11}=2.8 \times 10^{-10} \mathrm{~cm}^{3} \mathrm{~s}^{-1}$,

$$
\begin{aligned}
& \mathrm{N}_{2}\left(\mathrm{~A}^{3} \Sigma^{+}{ }_{\mathrm{u}}\right)+\mathrm{C}_{3} \mathrm{H}_{6} \rightarrow \text { products }+\mathrm{N}_{2} \\
& \mathrm{~N}_{2}\left(\mathrm{a}^{\prime}\right)+\mathrm{C}_{3} \mathrm{H}_{6} \rightarrow \text { products }+\mathrm{N}_{2}
\end{aligned}
$$

This rate constant was taken from Meyer et al. [43].

The products and the branching ratios given in table 2 for collisions of the nitrogen states with propene were determined in order to explain the measured concentration values for propene, ethane, and methane. In figure 5 are plotted results for $\mathrm{C}_{3} \mathrm{H}_{6}$. 


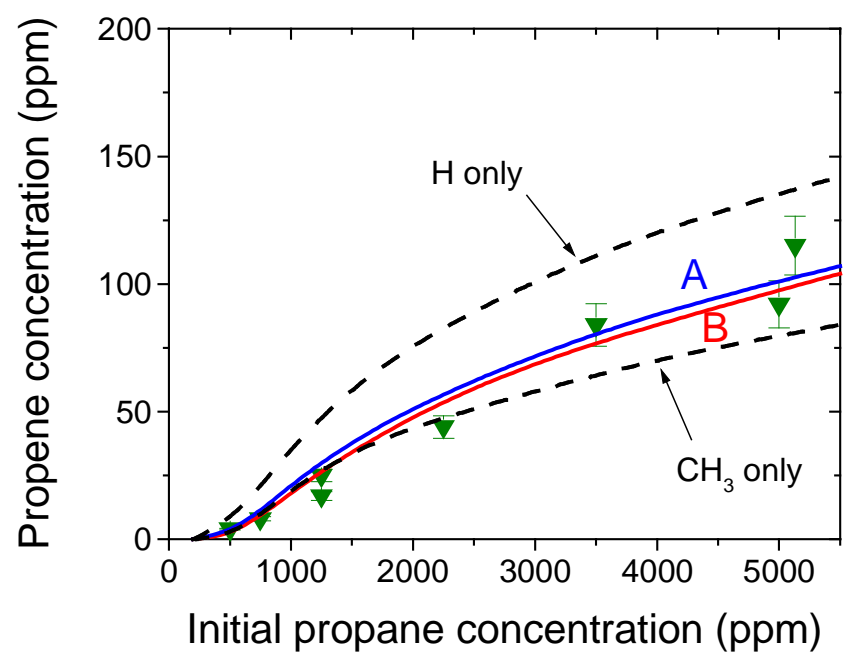

Figure 5. Propene concentration produced per current pulse in the discharge volume of the UV510 reactor. Lines : model predictions, see text for corresponding kinetic schemes, with different dissociation pathways for propene.

The most simplest hypothesis about $\mathrm{C}_{3} \mathrm{H}_{6}$ dissociation is to consider either the extraction of an hydrogen atom coming from the methyl group,

$$
\begin{aligned}
& \mathrm{N}_{2}\left(\mathrm{~A}^{3} \Sigma_{\mathrm{u}}^{+}\right)+\mathrm{C}_{3} \mathrm{H}_{6} \rightarrow \mathrm{CH}_{2}=\mathrm{CHCH}_{2}+\mathrm{H}+\mathrm{N}_{2} \\
& \mathrm{~N}_{2}\left(\mathrm{a}^{\prime}\right)+\mathrm{C}_{3} \mathrm{H}_{6} \rightarrow \mathrm{CH}_{2}=\mathrm{CHCH}_{2}+\mathrm{H}+\mathrm{N}_{2}
\end{aligned}
$$

or the break of the C-C bond,

$$
\begin{aligned}
& \mathrm{N}_{2}\left(\mathrm{~A}^{3} \Sigma_{\mathrm{u}}^{+}\right)+\mathrm{C}_{3} \mathrm{H}_{6} \rightarrow \mathrm{C}_{2} \mathrm{H}_{3}+\mathrm{CH}_{3}+\mathrm{N}_{2} \\
& \mathrm{~N}_{2}\left(\mathrm{a}^{\prime}\right)+\mathrm{C}_{3} \mathrm{H}_{6} \rightarrow \mathrm{C}_{2} \mathrm{H}_{3}+\mathrm{CH}_{3}+\mathrm{N}_{2}
\end{aligned}
$$

Here we applied the same reasoning than for propane, i.e. an intermediate excited state is produced which promptly dissociates. It gives results plotted in dashed lines in figure 5 (respectively denoted " $\mathrm{H}$ only" and " $\mathrm{CH}_{3}$ only"). The experimental points are within these predictions. For an initial propane concentration lower than $2500 \mathrm{ppm}$, the best agreement is obtained when only reactions (14) and (15) are taken into account. However the agreement can be roughly achieved on the whole range of propane concentration, line denoted $\mathrm{A}$ in figure 5 (case $\mathrm{A}$ ), if ones consider that both $\mathrm{H}$ and $\mathrm{CH}_{3}$ are produced with same probabilities.

The singlet states have enough energy to break the double $\mathrm{C}=\mathrm{C}$ bond (see table 4), i.e.

$$
\mathrm{N}_{2}\left(\mathrm{a}^{\prime}\right)+\mathrm{C}_{3} \mathrm{H}_{6} \rightarrow \mathrm{C}_{2} \mathrm{H}_{4}+\mathrm{CH}_{2}+\mathrm{N}_{2}
$$

Such a reaction is not energetically possible for the $\mathrm{A}^{3} \Sigma^{+}{ }_{\mathrm{u}}$ state but it can not a priori be disregarded for the a' state, and so it was included in the kinetic scheme, with $\mathrm{k}_{14}=2.8 \times 10^{-10} \mathrm{~cm}^{3} \mathrm{~s}^{-1}$, case B (line B in figure 5); in this case reactions (13) and (15) are not taken into account for the singlets. The results for cases A and B are very close. Then the role of reaction (16) on the concentration of propene appears not to be important, and we can not really conclude about the most probable products of collisions between the singlet states and propene. This remark is also valid for the ethane concentration, as it can be seen in figure 6. However the ethane concentration is very sensitive to the type of dissociation pathways, $\mathrm{H}$ or $\mathrm{CH}_{3}$, taken into account for the quenching of the $\mathrm{N}_{2}$ metastable states by propene. If only reaction (14) is considered, and (15) for $\mathrm{N}_{2}\left(\mathrm{a}^{\prime}\right)$, the concentration is strongly overestimated by the model. A much better agreement, over the whole range of $\mathrm{C}_{3} \mathrm{H}_{8}$ concentration values studied, between predictions and measurements is achieved for cases $\mathrm{A}$ and $\mathrm{B}$ (equal probability for the production of $\mathrm{H}$ and $\mathrm{CH}_{3}$ ), as it was established above for propene, figure 5. The " $\mathrm{H}$ only" case is not so far from experimental points in figure 6, but this case is not compatible with measurements for propene. 


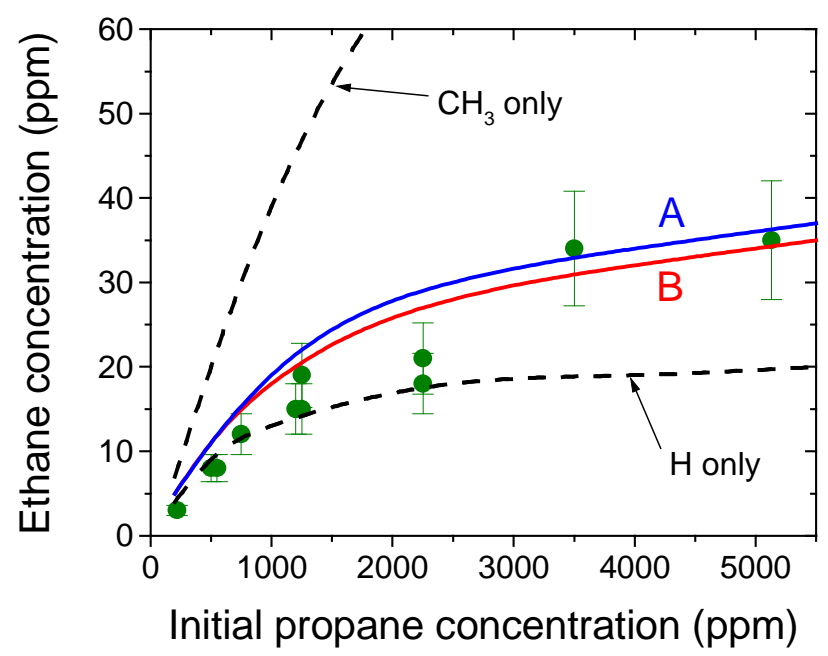

Figure 6. Ethane concentration produced per current pulse in the discharge volume of the UV510 reactor. Lines : model predictions, see text for corresponding kinetic schemes (A and B : same as in figure 5), with different dissociation pathways for propene.

The dissociation processes given in table 2 for $\mathrm{C}_{2} \mathrm{H}_{4}[20,24,26]$ and $\mathrm{C}_{2} \mathrm{H}_{2}[20,44]$ were also taken into account in the full kinetic scheme, for all cases which results are plotted in figures 5 and 6 . For acetylene, in absence of any data we chose a rate constant for the quenching of $\mathrm{N}_{2}\left(\mathrm{a}^{\prime}\right)$ a little higher than the known one for the $\mathrm{A}^{3} \Sigma^{+}{ }_{\mathrm{u}}$ state [41]. The sum of acetylene and ethene concentrations, denoted thereafter $\left[\mathrm{C}_{2}\right.$ unsat.], was measured in our experiment, so that we do not discuss separately model results for these two hydrocarbons. The measured $\left[\mathrm{C}_{2}\right.$ unsat.] values ranges from $10 \mathrm{ppm}$ up to $70 \mathrm{ppm}$ when the initial propane concentration, $\left[\mathrm{C}_{3} \mathrm{H}_{8}\right]_{0}$, increases from $500 \mathrm{ppm}$ up to $5000 \mathrm{ppm}$. The model predictions for the case A agree with measurements for $\left[\mathrm{C}_{3} \mathrm{H}_{8}\right]_{0}$ around $2000 \mathrm{ppm}$, but it is not so good at lower and higher $\left[\mathrm{C}_{3} \mathrm{H}_{8}\right]_{0}$ values (overestimation of $\left[\mathrm{C}_{2}\right.$ unsat.] for $\left[\mathrm{C}_{3} \mathrm{H}_{8}\right]_{0}<1500 \mathrm{ppm}$, underestimation for $\left[\mathrm{C}_{3} \mathrm{H}_{8}\right]_{0}>3000 \mathrm{ppm}$ ); nevertheless the mean difference is only a factor of 2 . The model gives an acetylene concentration higher than the ethylene one (concentration ratio between 2.5 and 10). At this stage of our study, a more precise knowledge of the acetylene kinetic is necessary to improve the agreement between computed and measured values for $\left[\mathrm{C}_{2}\right.$ unsat.]. Studies are needed for the $\mathrm{N}_{2} / \mathrm{C}_{2} \mathrm{H}_{2}$ mixture, in particular in order to get more precise data about collisions between the nitrogen metastable states and $\mathrm{C}_{2} \mathrm{H}_{2}$. This is out of the scope of this paper and will be the subject of future works.

\subsection{A minimum reaction scheme for propane and for the studied hydrocarbon by-products}

In the table 5 are listed the most important processes (between neutral species) for propane, propene, ethane, methane, and hydrogen. This set of reactions, in addition to the quenching processes of nitrogen states given in table 2 for case $\mathrm{A}$, stands for the minimum kinetic scheme necessary to explain our experimental results. Of course it can not be used to determine the carbon atom distribution following the electrical excitation of the $\mathrm{N}_{2} / \mathrm{C}_{3} \mathrm{H}_{8}$ mixture, because some species are considered as non reactive with radicals or molecules in table 5 and this is not correct for a comprehensive carbon balance. However this simplified kinetic scheme gives the same results than those displayed in figures 4 to 6 , case A. 
Table 5. List of neutral reactions for the minimum kinetic scheme. Reaction coefficients are given by the Arrhénius function :

$\mathrm{K} \rightarrow \mathrm{A} \mathrm{T}_{\mathrm{g}}{ }^{\mathrm{n}} \exp \left(-\mathrm{E} /\left(\mathrm{RT}_{\mathrm{g}}\right)\right)$ where $\mathrm{T}_{\mathrm{g}}$ is the gas mixture temperature (in $\mathrm{K}$ ).

$\mathrm{A}$ is given in units of $\mathrm{cm}^{3} \mathrm{~s}^{-1}$ for two body collisions and in $\mathrm{cm}^{6} \mathrm{~s}^{-1}$ for three body collisions.

\begin{tabular}{|c|c|c|c|c|}
\hline R1 : & $\mathrm{N}+\mathrm{H}+\mathrm{N}_{2} \rightarrow \mathrm{NH}+\mathrm{N}_{2}$ & $5.50(-31)$ & -0.5 & 0 \\
\hline R2 : & $\mathrm{N}+\mathrm{NH} \rightarrow \mathrm{N}_{2}+\mathrm{H}$ & $1.05(-12)$ & 0.5 & 0 \\
\hline R3 : & $\mathrm{NH}+\mathrm{NH} \rightarrow \mathrm{H}+\mathrm{N}_{2} \mathrm{H}$ & $1.32(-12)$ & 0.5 & -500 \\
\hline R4 : & $\mathrm{N}+\mathrm{CH}_{3} \rightarrow \mathrm{HCN}+\mathrm{H}_{2}$ & $3.90(-11)$ & 0 & -420 \\
\hline R5 : & $\mathrm{N}+\mathrm{CH}_{3} \rightarrow \mathrm{H}_{2} \mathrm{CN}+\mathrm{H}$ & $3.90(-10)$ & 0 & -420 \\
\hline R6 : & $\mathrm{N}+\mathrm{C}_{2} \mathrm{H}_{2} \rightarrow \mathrm{CH}+\mathrm{HCN}$ & $2.70(-15)$ & 0 & 0 \\
\hline R7 : & $\mathrm{N}+\mathrm{C}_{2} \mathrm{H}_{4} \rightarrow \mathrm{HCN}+\mathrm{CH}_{3}$ & $3.30(-14)$ & 0 & -353 \\
\hline R8 : & $\mathrm{N}+\mathrm{C}_{3} \mathrm{H}_{6} \rightarrow \mathrm{HCN}+\mathrm{C}_{2} \mathrm{H}_{5}$ & $1.94(-13)$ & 0 & -654 \\
\hline R9: & $\mathrm{N}+\mathrm{H}_{2} \mathrm{CN} \rightarrow \mathrm{HCN}+\mathrm{NH}$ & $6.70(-11)$ & 0 & 0 \\
\hline R10 : & $\mathrm{H}+\mathrm{H}_{2} \mathrm{CN} \rightarrow \mathrm{HCN}+\mathrm{H}_{2}$ & $2.90(-11)$ & 0.5 & 0 \\
\hline R11 (a) : & $\mathrm{H}+\mathrm{CH}_{3}+\mathrm{N}_{2} \rightarrow \mathrm{CH}_{4}+\mathrm{N}_{2}$ & $2.89(-26)$ & -1.15 & -175 \\
\hline R12 : & $\mathrm{H}+\mathrm{C}_{2} \mathrm{H}_{3} \rightarrow \mathrm{C}_{2} \mathrm{H}_{2}+\mathrm{H}_{2}$ & $2.00(-11)$ & 0 & 0 \\
\hline R13 : & $\mathrm{H}+\mathrm{C}_{2} \mathrm{H}_{5} \rightarrow \mathrm{CH}_{3}+\mathrm{CH}_{3}$ & $6.00(-11)$ & 0 & 0 \\
\hline R14 : & $\mathrm{H}+\mathrm{C}_{2} \mathrm{H}_{5} \rightarrow \mathrm{C}_{2} \mathrm{H}_{6}$ & $7.50(-11)$ & 0 & 0 \\
\hline R15 : & $\mathrm{H}+\mathrm{CH}_{2}=\mathrm{CHCH}_{2} \rightarrow \mathrm{C}_{3} \mathrm{H}_{6}$ & $1.40(-10)$ & 0 & 0 \\
\hline R16 : & $\mathrm{H}+\mathrm{CH}_{2}=\mathrm{CHCH}_{2} \rightarrow \mathrm{C}_{2} \mathrm{H}_{3}+\mathrm{CH}_{3}$ & $1.40(-10)$ & 0 & 0 \\
\hline R17 : & $\mathrm{H}+\mathrm{CH}_{2}=\mathrm{CHCH}_{2} \rightarrow \mathrm{H}_{2}+\mathrm{CH}_{2}=\mathrm{C}=\mathrm{CH}_{2}$ & $3.00(-11)$ & 0 & 0 \\
\hline R18 : & $\mathrm{H}+\mathrm{C}_{3} \mathrm{H}_{6} \rightarrow \mathrm{CH}_{2}=\mathrm{CHCH}_{2}+\mathrm{H}_{2}$ & $2.87(-19)$ & 2.5 & -1250 \\
\hline R19 : & $\mathrm{H}+\mathrm{C}_{3} \mathrm{H}_{6} \rightarrow \mathrm{CH}_{3}+\mathrm{C}_{2} \mathrm{H}_{4}$ & $7.51(-12)$ & 0 & -655 \\
\hline R20 : & $\mathrm{H}+\mathrm{C}_{3} \mathrm{H}_{6} \rightarrow$ iso- $\mathrm{C}_{3} \mathrm{H}_{7}$ & $2.16(-11)$ & 0 & -785 \\
\hline R21 (a) & $\mathrm{CH}_{3}+\mathrm{CH}_{3}+\mathrm{N}_{2} \rightarrow \mathrm{C}_{2} \mathrm{H}_{6}+\mathrm{N}_{2}$ & $1.23(-27)$ & -0.784 & -310 \\
\hline R22 : & $\mathrm{CH}_{3}+\mathrm{C}_{2} \mathrm{H}_{5} \rightarrow \mathrm{C}_{3} \mathrm{H}_{8}$ & $5.60(-11)$ & 0 & 0 \\
\hline R23 : & $\mathrm{CH}_{3}+\mathrm{CH}_{2}=\mathrm{CHCH}_{2} \rightarrow \mathrm{CH}_{2}=\mathrm{CHCH}_{2} \mathrm{CH}_{3}$ & $1.70(-10)$ & -0.32 & 66 \\
\hline R24 : & $\mathrm{C}_{2} \mathrm{H}_{3}+\mathrm{C}_{2} \mathrm{H}_{3} \rightarrow(\mathrm{E})-\mathrm{CH}_{2}=\mathrm{CHCH}=\mathrm{CH}_{2}$ & $1.60(-11)$ & 0 & 0 \\
\hline R25 : & $\mathrm{C}_{2} \mathrm{H}_{3}+\mathrm{C}_{2} \mathrm{H}_{3} \rightarrow \mathrm{C}_{2} \mathrm{H}_{2}+\mathrm{C}_{2} \mathrm{H}_{4}$ & $1.60(-12)$ & 0 & 0 \\
\hline R26 (b) : & $\mathrm{C}_{2} \mathrm{H}_{3}+\mathrm{CH}_{2}=\mathrm{CHCH}_{2} \rightarrow \mathrm{CH}_{2}=\mathrm{CHCH}_{2} \mathrm{CH}=\mathrm{CH}_{2}$ & $8.00(-11)$ & 0 & 0 \\
\hline R27 : & $\mathrm{C}_{2} \mathrm{H}_{3}+\mathrm{CH}_{2}=\mathrm{CHCH}_{2} \rightarrow \mathrm{C}_{3} \mathrm{H}_{6}+\mathrm{C}_{2} \mathrm{H}_{2}$ & $8.00(-12)$ & 0 & 0 \\
\hline R28 : & $\mathrm{C}_{2} \mathrm{H}_{3}+\mathrm{CH}_{2}=\mathrm{CHCH}_{2} \rightarrow \mathrm{CH}_{2}=\mathrm{C}=\mathrm{CH}_{2}+\mathrm{C}_{2} \mathrm{H}_{4}$ & $4.00(-12)$ & 0 & 0 \\
\hline R29 : & $\mathrm{C}_{2} \mathrm{H}_{5}+\mathrm{C}_{2} \mathrm{H}_{5} \rightarrow \mathrm{n}-\mathrm{C}_{4} \mathrm{H}_{10}$ & $1.90(-11)$ & 0 & 0 \\
\hline R30 : & $\mathrm{C}_{2} \mathrm{H}_{5}+\mathrm{CH}_{2}=\mathrm{CHCH}_{2} \rightarrow \mathrm{CH}_{3}\left(\mathrm{CH}_{2}\right)_{2} \mathrm{CH}=\mathrm{CH}_{2}$ & $3.30(-11)$ & 0 & 66 \\
\hline R31 : & $\begin{array}{l}\mathrm{CH}_{2}=\mathrm{CHCH}_{2}+\mathrm{CH}_{2}=\mathrm{CHCH}_{2} \rightarrow \\
\mathrm{CH}_{2}=\mathrm{CH}\left(\mathrm{CH}_{2}\right)_{2} \mathrm{CH}=\mathrm{CH}_{2}\end{array}$ & $1.70(-11)$ & 0 & 132 \\
\hline
\end{tabular}

(a) : rate constant only valid for the experimental conditions (total pressure and temperature values) of the present work.

(b) : exit route suppositional. 


\section{Overall description of propane conversion}

\subsection{Experimental results compared with kinetic model predictions}

The figure 7 gives final results about the concentrations of propane molecules and of the detected byproducts in the $\mathrm{N}_{2} / \mathrm{C}_{3} \mathrm{H}_{8}$ mixture, per current pulse in the discharge volume, for an initial hydrocarbon concentration value up to $5500 \mathrm{ppm}$. The dotted line shows the initial concentration, and other lines are model predictions for the full kinetic scheme (case A) discussed in the previous section.

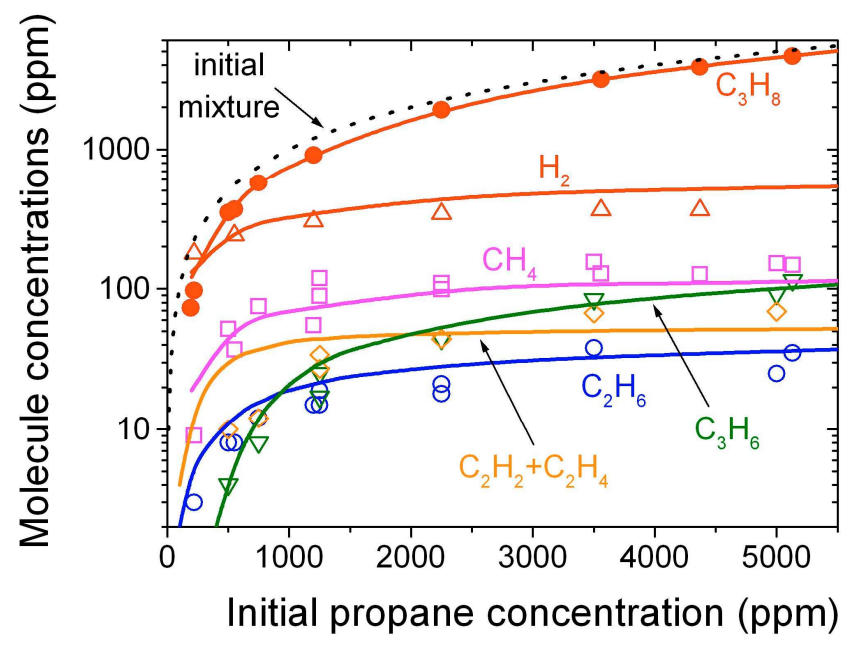

Figure 7. Propane and main by-products concentrations in the discharge volume of the UV510 reactor. Full lines : model predictions. Full symbols : $\mathrm{C}_{3} \mathrm{H}_{8}$; open symbols : $\mathrm{H}_{2}$ (up triangles), $\mathrm{CH}_{4}$ (squares), $\mathrm{C}_{2} \mathrm{H}_{2}$ and $\mathrm{C}_{2} \mathrm{H}_{4}$ (diamond), $\mathrm{C}_{2} \mathrm{H}_{6}$ (circles), $\mathrm{C}_{3} \mathrm{H}_{6}$ (down triangles).

An overall agreement is achieved between computation results and measurements if one considers, over the whole range of initial propane concentration values studied, the relative populations of byproducts : the most populated are $\mathrm{H}_{2}$ and $\mathrm{CH}_{4}$, followed by others.

Example of time evolution of species densities are plotted in figure 8a (most populated radicals) and figure $8 \mathrm{~b}$ (detected molecules), together with densities of $\mathrm{N}_{2}$ metastable states (dashed lines) and propane. For the chosen conditions the reactivity of the photo-triggered discharge excited mixture at 460 mbars total pressure is ended at $0.1 \mathrm{~s}$ (the zero time in these figures corresponds to the time of preionisation). The removal of propane arises mainly before $1 \mu \mathrm{s}$, and the effect of by-products dissociation processes (in particular propene) is clearly seen up to a time of $10 \mu \mathrm{s}$. 

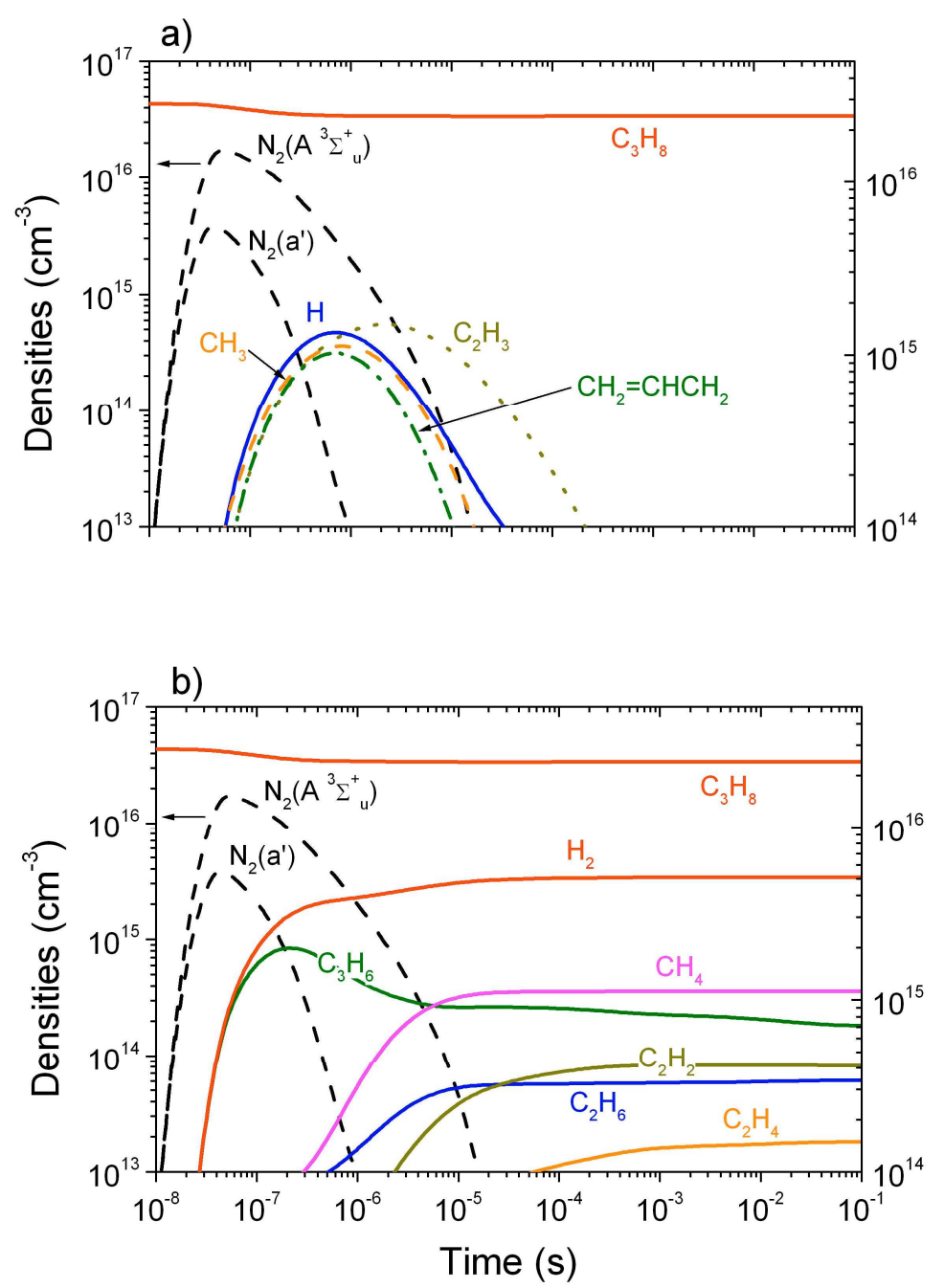

Figure 8. Time evolutions of species as predicted by the self-consistent discharge and kinetic model in the $\mathrm{N}_{2} / \mathrm{C}_{3} \mathrm{H}_{8}$ mixture at 460 mbars, for $2500 \mathrm{ppm}$ of hydrocarbon. The left hand $\mathrm{Y}$-axis is for the $\mathrm{N}_{2}$ metastable states only.

\subsection{Predicted carbon atom distribution}

The model emphasises that an important number of carbonated molecules should be produced for one current pulse in the $\mathrm{N}_{2} / \mathrm{C}_{3} \mathrm{H}_{8}$ mixture, in the discharge volume. In table 6 are given species which predicted concentration value is higher than $0.1 \mathrm{ppm}$ at $1 \mathrm{~s}$ for conditions of figures 8 . The molecules $\mathrm{HCN}$, (E) $-\mathrm{CH}_{2}=\mathrm{CHCH}=\mathrm{CH}_{2}$ (1,3-butadiene), and $\mathrm{CH}_{2}=\mathrm{CHCH}_{2} \mathrm{CH}=\mathrm{CH}_{2}$ (1,4-dipentene) are the most populated ones, followed by $\mathrm{CH}_{2}=\mathrm{C}=\mathrm{CH}_{2}$ (propadiene), $\mathrm{CH}_{2}=\mathrm{CHCH}_{2} \mathrm{CH}_{3}$ (1-butene), $\mathrm{CH}_{2}=\mathrm{CH}\left(\mathrm{CH}_{2}\right)_{2} \mathrm{CH}=\mathrm{CH}_{2}$ (1,5-hexadiene), and $\left(\mathrm{CH}_{3}\right)_{2} \mathrm{CHCH}=\mathrm{CH}_{2}$ (1-butene, 4-methyl). The concentrations of these compounds, in ppmC unit, are plotted in figure 9 as function of the initial carbon concentration, together with the converted carbon and the carbon contained in lighter molecules $\left(\mathrm{CH}_{4}, \mathrm{C}_{2} \mathrm{H}_{2}, \mathrm{C}_{2} \mathrm{H}_{4}, \mathrm{C}_{2} \mathrm{H}_{6}, \mathrm{C}_{3} \mathrm{H}_{6}\right)$ which were experimentally detected and quantified.

The cyanic acid has been detected in various experiments about atmospheric pressure discharges in $\mathrm{N}_{2} /$ hydrocarbon (either aliphatic or aromatic) mixtures [31-33, 50,51]. For conditions of figure 8, the main processes involved in the production of this molecule are, at short time during the afterglow, the reaction of the nitrogen atom with the methyl radical to form directly $\mathrm{HCN}$ or $\mathrm{H}_{2} \mathrm{CN}$, (R4) and (R5) in table 5, followed by reactions of $\mathrm{N}$ and $\mathrm{H}$-atoms with $\mathrm{H}_{2} \mathrm{CN}$, (R9) and (R10), and thus reaction of $\mathrm{N}$ with propene, (R8). 


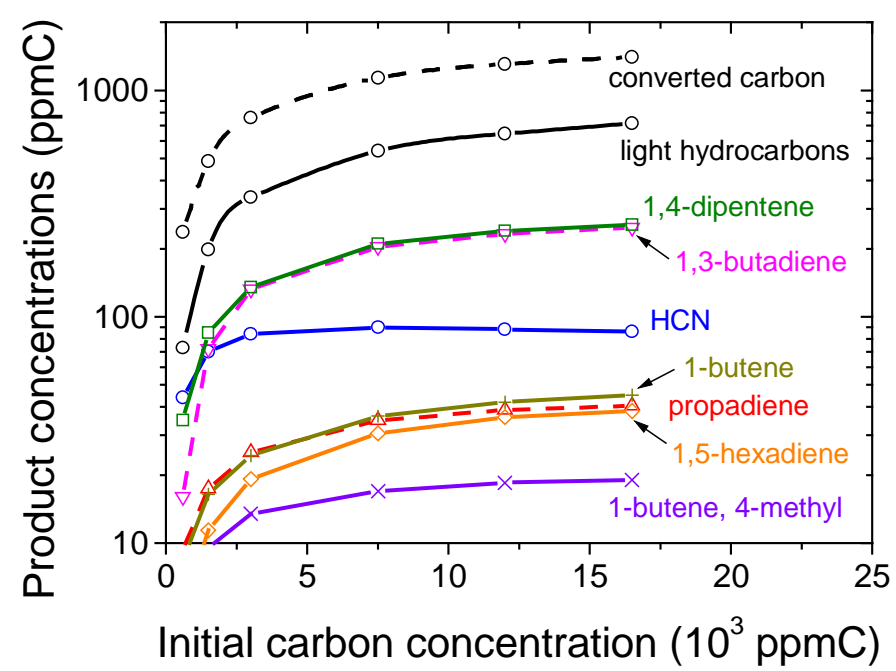

Figure 9. Concentrations (in ppmC) of the most populated carbonated species as predicted by the self-consistent discharge and kinetic model in the $\mathrm{N}_{2} / \mathrm{C}_{3} \mathrm{H}_{8}$ mixture at 460 mbars, for one current pulse, in the discharge volume. The line denoted as light hydrocarbons refers to the group $\left(\mathrm{CH}_{4}, \mathrm{C}_{2} \mathrm{H}_{2}, \mathrm{C}_{2} \mathrm{H}_{4}, \mathrm{C}_{2} \mathrm{H}_{6}, \mathrm{C}_{3} \mathrm{H}_{6}\right)$.

1,3-butadiene is mainly produced by reaction of $\mathrm{CH}_{2}$ with $\mathrm{CH}_{2}=\mathrm{CHCH}_{2}(\mathrm{C} 65$ in appendix $\mathrm{C})$ and by the self-reaction of $\mathrm{C}_{2} \mathrm{H}_{3}$ (R24 in table 5), whereas 1,4-dipentene should be obtained by addition of $\mathrm{C}_{2} \mathrm{H}_{3}$ to $\mathrm{CH}_{2}=\mathrm{CHCH}_{2}$ (R26, the exit route of this reaction is suppositional), all these radicals coming from $\mathrm{C}_{3} \mathrm{H}_{6}$. Nitrogen states are also efficiently quenched by 1,3-butadiene [20] and probably also by 1,4-dipentene, but we have checked for 1,3-butadiene that such collisions have a negligible effect on results presented above. The quenching of $\mathrm{N}_{2}$ states by $\mathrm{HCN}$ [20] has also a weak influence.

The species cited above were not all identified by chromatography in the total device volume. Species should be detectable at the condition that, first, the produced concentration is high enough in the discharge volume and, secondly, it is not effectively treated by the following current pulse after dilution (dilution factor equal to 180). According to results displayed in figure 2, it appears to be fulfilled for hydrogen and light hydrocarbons. 
Table 6. Predicted concentration (higher than $0.1 \mathrm{ppm}$ ) of species (other than those detected and quantified by chromatography) in the late afterglow, for conditions of figure 8 .

\begin{tabular}{|c|c|c|}
\hline \multirow{2}{*}{ Molecules } & \multicolumn{2}{|c|}{ Concentration } \\
\hline & ppm & ppmC \\
\hline $\mathrm{HCN}$ & 90 & 90 \\
\hline (E) $-\mathrm{CH}_{2}=\mathrm{CHCH}=\mathrm{CH}_{2}$ & 51 & 204 \\
\hline $\mathrm{CH}_{2}=\mathrm{CHCH}_{2} \mathrm{CH}=\mathrm{CH}_{2}$ & 42 & 210 \\
\hline $\mathrm{CH}_{2}=\mathrm{C}=\mathrm{CH}_{2}$ & 12 & 36 \\
\hline $\mathrm{CH}_{2}=\mathrm{CHCH}_{2} \mathrm{CH}_{3}$ & 9.1 & 36 \\
\hline $\mathrm{CH}_{2}=\mathrm{CH}\left(\mathrm{CH}_{2}\right)_{2} \mathrm{CH}=\mathrm{CH}_{2}$ & 5.1 & 31 \\
\hline$\left(\mathrm{CH}_{3}\right)_{2} \mathrm{CHCH}=\mathrm{CH}_{2}$ & 3.4 & 17 \\
\hline $\mathrm{n}-\mathrm{C}_{4} \mathrm{H}_{10}$ & 2.4 & 9.6 \\
\hline $\mathrm{CH}_{3}\left(\mathrm{CH}_{2}\right)_{2} \mathrm{CH}=\mathrm{CH}_{2}$ & 1.9 & 9.5 \\
\hline iso- $\mathrm{C}_{5} \mathrm{H}_{12}$ & 1.3 & 6.5 \\
\hline$\left(\mathrm{CH}_{3}\right)_{2} \mathrm{CHCH}\left(\mathrm{CH}_{3}\right)_{2}$ & 0.54 & 3.2 \\
\hline $\mathrm{CH}_{2}=\mathrm{CHCH}_{2} \mathrm{C} \equiv \mathrm{CH}$ & 0.44 & 2.2 \\
\hline iso- $\mathrm{C}_{6} \mathrm{H}_{14}$ & 0.42 & 2.5 \\
\hline iso- $\mathrm{C}_{4} \mathrm{H}_{10}$ & 0.38 & 1.5 \\
\hline $\mathrm{HC} \equiv \mathrm{CC} \equiv \mathrm{CH}$ & 0.38 & 1.5 \\
\hline $\mathrm{n}-\mathrm{C}_{5} \mathrm{H}_{12}$ & 0.31 & 1.5 \\
\hline $\mathrm{C}_{2} \mathrm{H}_{5} \mathrm{C} \equiv \mathrm{CH}$ & 0.29 & 1.2 \\
\hline $\mathrm{CH}_{3} \mathrm{C} \equiv \mathrm{CH}$ & 0.26 & 0.8 \\
\hline $\mathrm{CH}_{3}\left(\mathrm{CH}_{2}\right)_{3} \mathrm{CH}=\mathrm{CH}_{2}$ & 0.18 & 1.1 \\
\hline$\left(\mathrm{CH}_{3}\right)_{2} \mathrm{CHCH}_{2} \mathrm{CH}=\mathrm{CH}_{2}$ & 0.15 & 0.9 \\
\hline
\end{tabular}

\section{Conclusion}

The removal and conversion processes of propane in $\mathrm{N}_{2} / \mathrm{C}_{3} \mathrm{H}_{8}$ mixtures (concentration of hydrocarbon molecules up to $5500 \mathrm{ppm}$ ) energised by a photo-triggered discharge (homogeneous plasma) were studied at 460 mbar total pressure by chromatography and comparison of experimental results with predictions of a 0D self-consistent discharge and detailed plasma kinetic model.

Quenchings of nitrogen metastable states are the more important processes for the removal of the hydrocarbon molecule. As previously found for ethane, the estimated rate constant for collisions of the singlet states with $\mathrm{C}_{3} \mathrm{H}_{8}, 3.0 \times 10^{-10} \mathrm{~cm}^{3} \mathrm{~s}^{-1}$, is more than two order of magnitude higher than the one for the $\mathrm{A}^{3} \Sigma^{+}{ }_{\mathrm{u}}$ state. The more probable dissociation products are $\mathrm{H}_{2}$ and $\mathrm{C}_{3} \mathrm{H}_{6}$. Following the removal of propane, the carbon atoms are distributed amongst many compounds. The most populated ones are $\mathrm{HCN}, \mathrm{CH}_{4}, \mathrm{C}_{2} \mathrm{H}_{2}, \mathrm{C}_{2} \mathrm{H}_{4}, \mathrm{C}_{2} \mathrm{H}_{6}, \mathrm{C}_{3} \mathrm{H}_{6}, 1,3$-butadiene and probably 1,4-dipentene. The propene molecule is also efficiently dissociated by quenching processes of $\mathrm{N}_{2}$ states, and probably leads to the production of hydrogen atoms and methyl radicals with equivalent probabilities. The hydrogen molecule is the most populated by-products coming from the $\mathrm{N}_{2} / \mathrm{C}_{3} \mathrm{H}_{8}$ mixture excited by the phototriggered discharge.

Further studies should be dedicated to a more precise analysis of minor by-products (identification of compounds and measurement of their concentrations). The relative production of acetylene and ethene deserves also to be studied in more detail. In this way experiments and modelling of the $\mathrm{C}_{2} \mathrm{H}_{2}$ removal by a photo-triggered discharge should be of interest. Moreover, our results are deduced from 
Propane dissociation in a nitrogen plasma

of a global analysis of the $\mathrm{N}_{2} / \mathrm{C}_{3} \mathrm{H}_{8}$ plasma kinetic. More dedicated experiments for each proposed dissociation mechanisms should bring more information on such processes.

\section{Acknowledgments}

This work was supported by the French National Agency of Research (Agence Nationale pour la Recherche) under contract $n^{\circ}$ ANR-05-BLAN-0181. 


\section{Appendix A}

Ions and neutral species taken into account in the model, for the full kinetic scheme (except nitrogen molecular excited states, see [23]) are given in table A1.

\section{Table A1.}

\begin{tabular}{|c|c|c|c|}
\hline $\mathrm{N}^{+}$ & $\mathrm{N}$ & $\mathrm{C}$ & $\mathrm{HC} \equiv \mathrm{CC} \equiv \mathrm{CH}$ \\
\hline $\mathrm{N}_{2}^{+}$ & $\mathrm{NH}$ & $\mathrm{CH}$ & $\mathrm{CH}_{2}=\mathrm{CHC} \equiv \mathrm{CH}$ \\
\hline $\mathrm{N}_{3}^{+}$ & $\mathrm{NH}_{2}$ & $\mathrm{CH}_{2}$ & $\mathrm{C}_{2} \mathrm{H}_{5} \mathrm{C} \equiv \mathrm{CH}$ \\
\hline $\mathrm{N}_{4}^{+}$ & $\mathrm{NH}_{3}$ & $\mathrm{CH}_{3}$ & $\mathrm{CH}_{2}=\mathrm{C}=\mathrm{CHCH}_{3}$ \\
\hline $\mathrm{C}_{2} \mathrm{H}_{2}^{+}$ & $\mathrm{N}_{2} \mathrm{H}$ & $\mathrm{CH}_{4}$ & (E) $\mathrm{CH}_{2}=\mathrm{CHCH}=\mathrm{CH}_{2}$ \\
\hline $\mathrm{C}_{2} \mathrm{H}_{3}^{+}$ & $\mathrm{N}_{2} \mathrm{H}_{2}$ & $\mathrm{C}_{2}$ & $\mathrm{CH}_{2}=\mathrm{CHCH}_{2} \mathrm{CH}_{3}$ \\
\hline $\mathrm{C}_{2} \mathrm{H}_{4}^{+}$ & $\mathrm{N}_{2} \mathrm{H}_{4}$ & $\mathrm{C}_{2} \mathrm{H}$ & $\mathrm{CH}_{3} \mathrm{CH}=\mathrm{CHCH}_{3}$ \\
\hline $\mathrm{C}_{2} \mathrm{H}_{5}^{+}$ & $\mathrm{CN}$ & $\mathrm{C}_{2} \mathrm{H}_{2}$ & $1-\mathrm{C}_{4} \mathrm{H}_{9}$ \\
\hline $\mathrm{C}_{2} \mathrm{H}_{6}^{+}$ & $\mathrm{HCN}$ & $\mathrm{C}_{2} \mathrm{H}_{3}$ & $\mathrm{n}-\mathrm{C}_{4} \mathrm{H}_{10}$ \\
\hline $\mathrm{C}_{3} \mathrm{H}_{5}^{+}$ & $\mathrm{H}_{2} \mathrm{CN}$ & $\mathrm{C}_{2} \mathrm{H}_{4}$ & iso- $\mathrm{C}_{4} \mathrm{H}_{10}$ \\
\hline $\mathrm{C}_{3} \mathrm{H}_{7}^{+}$ & $\mathrm{CH}_{2} \mathrm{NH}$ & $\mathrm{C}_{2} \mathrm{H}_{5}$ & $\mathrm{CH}_{2}=\mathrm{CHCH}_{2} \mathrm{C} \equiv \mathrm{CH}$ \\
\hline $\mathrm{C}_{3} \mathrm{H}_{8}^{+}$ & $\mathrm{CHCN}$ & $\mathrm{C}_{2} \mathrm{H}_{6}$ & $\mathrm{CH}_{2}=\mathrm{CHCH}_{2} \mathrm{CH}=\mathrm{CH}_{2}$ \\
\hline $\mathrm{HCN}^{+}$ & $\mathrm{CH}_{2} \mathrm{~N}_{2}=\mathrm{CH}_{2}$ & $\mathrm{CH}_{2}=\mathrm{C}=\mathrm{CH}$ & $\mathrm{CH}_{3}\left(\mathrm{CH}_{2}\right)_{2} \mathrm{CH}=\mathrm{CH}_{2}$ \\
\hline $\mathrm{H}_{2} \mathrm{CN}^{+}$ & & $\mathrm{CH}_{2}=\mathrm{C}=\mathrm{CH}_{2}$ & $\left(\mathrm{CH}_{3}\right)_{2} \mathrm{CHCH}=\mathrm{CH}_{2}$ \\
\hline $\mathrm{C}_{2} \mathrm{~N}^{+}$ & & $\mathrm{CH}_{3} \mathrm{C} \equiv \mathrm{CH}$ & $\mathrm{n}-\mathrm{C}_{5} \mathrm{H}_{12}$ \\
\hline \multirow[t]{7}{*}{$\mathrm{CHCN}^{+}$} & & $\mathrm{CH}_{2}=\mathrm{CHCH}_{2}$ & iso- $\mathrm{C}_{5} \mathrm{H}_{12}$ \\
\hline & & $\mathrm{CH}_{2}=\mathrm{CCH}_{3}$ & $\mathrm{CH}_{2}=\mathrm{CH}\left(\mathrm{CH}_{2}\right)_{2} \mathrm{CH}=\mathrm{CH}_{2}$ \\
\hline & & $\mathrm{CH}_{3} \mathrm{CH}=\mathrm{CH}$ & $\mathrm{CH}_{3}\left(\mathrm{CH}_{2}\right)_{3} \mathrm{CH}=\mathrm{CH}_{2}$ \\
\hline & & $\mathrm{C}_{3} \mathrm{H}_{6}$ & $\left(\mathrm{CH}_{3}\right)_{2} \mathrm{CHCH}_{2} \mathrm{CH}=\mathrm{CH}_{2}$ \\
\hline & & $\mathrm{n}-\mathrm{C}_{3} \mathrm{H}_{7}$ & $\mathrm{n}-\mathrm{C}_{6} \mathrm{H}_{14}$ \\
\hline & & iso- $\mathrm{C}_{3} \mathrm{H}_{7}$ & iso- $\mathrm{C}_{6} \mathrm{H}_{14}$ \\
\hline & & $\mathrm{C}_{3} \mathrm{H}_{8}$ & $\left(\mathrm{CH}_{3}\right)_{2} \mathrm{CHCH}\left(\mathrm{CH}_{3}\right)_{2}$ \\
\hline
\end{tabular}




\section{Appendix B}

The kinetic processes taken into account in the model for collisions between carbonated ions and molecules given in appendix A are listed in table B1.

Table B1. Reaction coefficients are given in units of $\mathrm{cm}^{3} \mathrm{~s}^{-1}$.

\begin{tabular}{|c|c|c|}
\hline & Reaction & Coefficient \\
\hline B1 & $\mathrm{N}_{2}^{+}+\mathrm{C}_{3} \mathrm{H}_{8} \rightarrow \mathrm{C}_{3} \mathrm{H}_{5}^{+}+\mathrm{H}_{2}+\mathrm{H}+\mathrm{N}_{2}$ & $1.7(-10)$ \\
\hline B2 & $\mathrm{N}_{2}^{+}+\mathrm{C}_{3} \mathrm{H}_{8} \rightarrow \mathrm{C}_{2} \mathrm{H}_{5}^{+}+\mathrm{CH}_{3}+\mathrm{N}_{2}$ & $3.9(-10)$ \\
\hline B3 & $\mathrm{N}_{2}^{+}+\mathrm{C}_{3} \mathrm{H}_{8} \rightarrow \mathrm{C}_{2} \mathrm{H}_{4}^{+}+\mathrm{CH}_{4}+\mathrm{N}_{2}$ & $2.2(-10)$ \\
\hline B4 & $\mathrm{N}_{2}^{+}+\mathrm{C}_{3} \mathrm{H}_{8} \rightarrow \mathrm{C}_{2} \mathrm{H}_{3}^{+}+\mathrm{CH}_{3}+\mathrm{H}_{2}+\mathrm{N}_{2}$ & $5.2(-10)$ \\
\hline B5 & $\mathrm{N}_{4}^{+}+\mathrm{C}_{3} \mathrm{H}_{8} \rightarrow \mathrm{C}_{3} \mathrm{H}_{7}^{+}+\mathrm{H}+\mathrm{H}_{2}+\mathrm{N}_{2}+\mathrm{N}_{2}$ & $1.2(-10)$ \\
\hline B6 & $\mathrm{N}_{4}^{+}+\mathrm{C}_{3} \mathrm{H}_{8} \rightarrow \mathrm{C}_{2} \mathrm{H}_{5}^{+}+\mathrm{CH}_{3}+\mathrm{N}_{2}+\mathrm{N}_{2}$ & $6.7(-10)$ \\
\hline B7 & $\mathrm{N}_{4}^{+}+\mathrm{C}_{3} \mathrm{H}_{8} \rightarrow \mathrm{C}_{2} \mathrm{H}_{4}^{+}+\mathrm{CH}_{4}+\mathrm{N}_{2}+\mathrm{N}_{2}$ & $4.3(-10)$ \\
\hline B8 & $\mathrm{C}_{2} \mathrm{H}_{3}^{+}+\mathrm{N} \rightarrow \mathrm{CHCN}^{+}+\mathrm{H}_{2}$ & $2.2(-10)$ \\
\hline B9 & $\mathrm{C}_{2} \mathrm{H}_{3}^{+}+\mathrm{H} \rightarrow \mathrm{C}_{2} \mathrm{H}_{2}^{+}+\mathrm{H}_{2}$ & $1.0(-10)$ \\
\hline B10 & $\mathrm{C}_{2} \mathrm{H}_{3}^{+}+\mathrm{CH}_{4} \rightarrow \mathrm{C}_{3} \mathrm{H}_{5}^{+}+\mathrm{H}_{2}$ & $1.9(-10)$ \\
\hline B11 & $\mathrm{C}_{2} \mathrm{H}_{3}^{+}+\mathrm{C}_{3} \mathrm{H}_{8} \rightarrow \mathrm{C}_{2} \mathrm{H}_{5}^{+}+\mathrm{CH}_{3} \mathrm{CH}=\mathrm{CH}$ & $3.35(-10)$ \\
\hline B12 & $\mathrm{C}_{2} \mathrm{H}_{3}^{+}+\mathrm{C}_{3} \mathrm{H}_{8} \rightarrow \mathrm{C}_{3} \mathrm{H}_{5}^{+}+\mathrm{C}_{3} \mathrm{H}_{6}$ & $3.35(-10)$ \\
\hline B13 & $\mathrm{C}_{2} \mathrm{H}_{4}^{+}+\mathrm{H} \rightarrow \mathrm{C}_{2} \mathrm{H}_{3}^{+}+\mathrm{H}_{2}$ & $3.3(-10)$ \\
\hline B14 & $\mathrm{C}_{2} \mathrm{H}_{4}^{+}+\mathrm{C}_{3} \mathrm{H}_{8} \rightarrow \mathrm{C}_{3} \mathrm{H}_{7}^{+}+\mathrm{C}_{2} \mathrm{H}_{5}$ & $8.5(-10)$ \\
\hline B15 & $\mathrm{C}_{2} \mathrm{H}_{5}^{+}+\mathrm{H} \rightarrow \mathrm{C}_{2} \mathrm{H}_{4}^{+}+\mathrm{H}_{2}$ & $1.0(-11)$ \\
\hline B16 & $\mathrm{C}_{2} \mathrm{H}_{5}^{+}+\mathrm{CH}_{4} \rightarrow \mathrm{C}_{3} \mathrm{H}_{7}^{+}+\mathrm{H}_{2}$ & $9.0(-14)$ \\
\hline B17 & $\mathrm{C}_{2} \mathrm{H}_{5}^{+}+\mathrm{C}_{3} \mathrm{H}_{8} \rightarrow \mathrm{C}_{3} \mathrm{H}_{7}^{+}+\mathrm{C}_{2} \mathrm{H}_{6}$ & $6.3(-10)$ \\
\hline B18 & $\mathrm{C}_{2} \mathrm{H}_{5}^{+}+\mathrm{N} \rightarrow \mathrm{C}_{2} \mathrm{H}_{4}^{+}+\mathrm{HCN}$ & $1.1(-10)$ \\
\hline B19 & $\mathrm{C}_{3} \mathrm{H}_{5}^{+}+\mathrm{C}_{3} \mathrm{H}_{8} \rightarrow$ product $+\mathrm{C}_{2} \mathrm{H}_{6}$ & $1.8(-10)$ \\
\hline
\end{tabular}




\section{Appendix C}

The kinetic processes taken into account in the model for neutral species given in appendix A are listed in table $\mathrm{C} 1$.

Table C1. Reaction coefficients are given by the Arrhénius function :

$\mathrm{K} \rightarrow \mathrm{A} \mathrm{T}_{\mathrm{g}}{ }^{\mathrm{n}} \exp \left(-\mathrm{E} /\left(\mathrm{RT}_{\mathrm{g}}\right)\right.$ ) where $\mathrm{T}_{\mathrm{g}}$ is the gas mixture temperature (in $\mathrm{K}$ ).

$\mathrm{A}$ is given in units of $\mathrm{cm}^{3} \mathrm{~s}^{-1}$ for two body collisions and in $\mathrm{cm}^{6} \mathrm{~s}^{-1}$ for three body collisions.

\begin{tabular}{|c|c|c|c|c|}
\hline & & A & $\mathrm{n}$ & $-E / R$ \\
\hline \multicolumn{5}{|c|}{ Nitrogen compounds } \\
\hline $\mathrm{C} 1$ & $\mathrm{~N}+\mathrm{CH} \rightarrow \mathrm{CN}+\mathrm{H}$ & $2.10(-11)$ & 0 & 0 \\
\hline $\mathrm{C} 2$ & $\mathrm{~N}+\mathrm{CH}_{2} \rightarrow \mathrm{H}_{2}+\mathrm{CN}$ & $1.60(-11)$ & 0 & 0 \\
\hline $\mathrm{C} 3$ & $\mathrm{H}+\mathrm{NH}_{2} \rightarrow \mathrm{NH}+\mathrm{H}_{2}$ & $1.00(-11)$ & 0 & 0 \\
\hline C4 (a) & $\mathrm{H}+\mathrm{HCN}+\mathrm{N}_{2} \rightarrow \mathrm{H}_{2} \mathrm{CN}+\mathrm{N}_{2}$ & $4.84(-30)$ & 0 & -2440 \\
\hline $\mathrm{C} 5$ & $\mathrm{NH}+\mathrm{NH} \rightarrow \mathrm{NH}_{2}+\mathrm{N}$ & $3.30(-13)$ & 0.5 & -1000 \\
\hline C6 & $\mathrm{NH}+\mathrm{NH}_{2} \rightarrow \mathrm{H}+\mathrm{N}_{2} \mathrm{H}_{2}$ & $5.25(-11)$ & 0 & -500 \\
\hline $\mathrm{C} 7$ & $\mathrm{NH}_{2}+\mathrm{NH}_{2} \rightarrow \mathrm{H}_{2}+\mathrm{N}_{2} \mathrm{H}_{2}$ & $6.60(-11)$ & 0 & -6000 \\
\hline $\mathrm{C} 8$ & $\mathrm{NH}_{2}+\mathrm{NH}_{2} \rightarrow \mathrm{NH}+\mathrm{NH}_{3}$ & $8.30(-11)$ & 0 & -5030 \\
\hline C9 & $\mathrm{NH}_{2}+\mathrm{NH}_{2} \rightarrow \mathrm{N}_{2} \mathrm{H}_{4}$ & $8.00(-11)$ & 0 & 0 \\
\hline $\mathrm{C} 10$ & $\mathrm{H}_{2} \mathrm{CN}+\mathrm{H}_{2} \mathrm{CN} \rightarrow \mathrm{CH}_{2} \mathrm{~N}_{2}=\mathrm{CH}_{2}$ & $2.00(-12)$ & 0 & 0 \\
\hline C11 & $\mathrm{H}_{2} \mathrm{CN}+\mathrm{H}_{2} \mathrm{CN} \rightarrow \mathrm{HCN}+\mathrm{CH}_{2} \mathrm{NH}$ & $3.85(-12)$ & 0 & 0 \\
\hline \multicolumn{5}{|c|}{ Propane reactions } \\
\hline $\mathrm{C} 12$ & $\mathrm{H}+\mathrm{C}_{3} \mathrm{H}_{8} \rightarrow \mathrm{H}_{2}+\mathrm{n}-\mathrm{C}_{3} \mathrm{H}_{7}$ & $2.20(-18)$ & 2.54 & -3400 \\
\hline $\mathrm{C} 13$ & $\mathrm{H}+\mathrm{C}_{3} \mathrm{H}_{8} \rightarrow \mathrm{H}_{2}+$ iso- $\mathrm{C}_{3} \mathrm{H}_{7}$ & $2.16(-18)$ & 2.40 & -2250 \\
\hline C14 & $\mathrm{CH}+\mathrm{C}_{3} \mathrm{H}_{8} \rightarrow \mathrm{H}+\mathrm{CH}_{2}=\mathrm{CHCH}_{2} \mathrm{CH}_{3}$ & $1.91(-10)$ & 0 & 240 \\
\hline $\mathrm{C} 15$ & $\mathrm{CH}_{2}+\mathrm{C}_{3} \mathrm{H}_{8} \rightarrow \mathrm{n}-\mathrm{C}_{4} \mathrm{H}_{10}$ & $8.14(-12)$ & 0 & -3330 \\
\hline $\mathrm{C} 16$ & $\mathrm{C}_{2} \mathrm{H}+\mathrm{C}_{3} \mathrm{H}_{8} \rightarrow \mathrm{C}_{2} \mathrm{H}_{2}+\mathrm{n}-\mathrm{C}_{3} \mathrm{H}_{7}$ & $6.00(-12)$ & 0 & 0 \\
\hline $\mathrm{C} 17$ & $\mathrm{C}_{2} \mathrm{H}+\mathrm{C}_{3} \mathrm{H}_{8} \rightarrow \mathrm{C}_{2} \mathrm{H}_{2}+$ iso- $\mathrm{C}_{3} \mathrm{H}_{7}$ & $2.00(-12)$ & 0 & 0 \\
\hline $\mathrm{C} 18$ & $\mathrm{H}+$ iso- $\mathrm{C}_{3} \mathrm{H}_{7} \rightarrow \mathrm{C}_{3} \mathrm{H}_{8}$ & $3.32(-11)$ & 0 & 0 \\
\hline C19 & $\mathrm{C}_{2} \mathrm{H}_{3}+$ iso- $\mathrm{C}_{3} \mathrm{H}_{7} \rightarrow \mathrm{C}_{3} \mathrm{H}_{8}+\mathrm{C}_{2} \mathrm{H}_{2}$ & $2.54(-10)$ & -0.7 & 0 \\
\hline $\mathrm{C} 20$ & $\mathrm{C}_{2} \mathrm{H}_{3}+\mathrm{n}-\mathrm{C}_{3} \mathrm{H}_{7} \rightarrow \mathrm{C}_{3} \mathrm{H}_{8}+\mathrm{C}_{2} \mathrm{H}_{2}$ & $2.00(-12)$ & 0 & 0 \\
\hline $\mathrm{C} 21$ & $\mathrm{C}_{2} \mathrm{H}_{5}+$ iso- $\mathrm{C}_{3} \mathrm{H}_{7} \rightarrow \mathrm{C}_{3} \mathrm{H}_{8}+\mathrm{C}_{2} \mathrm{H}_{4}$ & $3.06(-11)$ & -0.35 & 0 \\
\hline $\mathrm{C} 22$ & $\mathrm{C}_{2} \mathrm{H}_{5}+\mathrm{n}-\mathrm{C}_{3} \mathrm{H}_{7} \rightarrow \mathrm{C}_{3} \mathrm{H}_{8}+\mathrm{C}_{2} \mathrm{H}_{4}$ & $1.92(-12)$ & 0 & 0 \\
\hline $\mathrm{C} 23$ & $\mathrm{CH}_{2}=\mathrm{CHCH}_{2}+$ iso- $\mathrm{C}_{3} \mathrm{H}_{7} \rightarrow \mathrm{C}_{3} \mathrm{H}_{8}+\mathrm{CH}_{2}=\mathrm{C}=\mathrm{CH}_{2}$ & $7.61(-12)$ & -0.35 & 66 \\
\hline $\mathrm{C} 24$ & $\mathrm{CH}_{2}=\mathrm{CHCH}_{2}+\mathrm{n}-\mathrm{C}_{3} \mathrm{H}_{7} \rightarrow \mathrm{C}_{3} \mathrm{H}_{8}+\mathrm{CH}_{2}=\mathrm{C}=\mathrm{CH}_{2}$ & $1.20(-12)$ & 0 & 66 \\
\hline $\mathrm{C} 25$ & iso- $\mathrm{C}_{3} \mathrm{H}_{7}+$ iso- $\mathrm{C}_{3} \mathrm{H}_{7} \rightarrow \mathrm{C}_{3} \mathrm{H}_{8}+\mathrm{C}_{3} \mathrm{H}_{6}$ & $4.25(-12)$ & 0 & 0 \\
\hline $\mathrm{C} 26$ & iso- $\mathrm{C}_{3} \mathrm{H}_{7}+\mathrm{n}-\mathrm{C}_{3} \mathrm{H}_{7} \rightarrow \mathrm{C}_{3} \mathrm{H}_{8}+\mathrm{C}_{3} \mathrm{H}_{6}$ & $2.69(-14)$ & -0.35 & 0 \\
\hline $\mathrm{C} 27$ & $\mathrm{n}-\mathrm{C}_{3} \mathrm{H}_{7}+\mathrm{n}-\mathrm{C}_{3} \mathrm{H}_{7} \rightarrow \mathrm{C}_{3} \mathrm{H}_{8}+\mathrm{C}_{3} \mathrm{H}_{6}$ & $2.81(-12)$ & 0 & 0 \\
\hline \multicolumn{5}{|c|}{ Other reactions } \\
\hline $\mathrm{C} 28$ & $\mathrm{H}+\mathrm{H}+\mathrm{N}_{2} \rightarrow \mathrm{H}_{2}+\mathrm{N}_{2}$ & $1.50(-29)$ & -1.30 & 0 \\
\hline $\mathrm{C} 29$ & $\mathrm{H}+\mathrm{CH} \rightarrow \mathrm{H}_{2}+\mathrm{C}$ & $1.00(-12)$ & 0.5 & -4000 \\
\hline $\mathrm{C} 30$ & $\mathrm{H}+\mathrm{CH}_{2} \rightarrow \mathrm{H}_{2}+\mathrm{CH}$ & $1.00(-11)$ & 0 & 900 \\
\hline
\end{tabular}




\begin{tabular}{|c|c|c|c|c|}
\hline $\mathrm{C} 31$ & $\mathrm{H}+\mathrm{CH}_{3} \rightarrow \mathrm{H}_{2}+\mathrm{CH}_{2}$ & $1.00(-10)$ & 0 & -7600 \\
\hline $\mathrm{C} 32$ & $\mathrm{H}+\mathrm{CH}_{4} \rightarrow \mathrm{H}_{2}+\mathrm{CH}_{3}$ & $2.20(-20)$ & 3 & -4050 \\
\hline $\mathrm{C} 33$ & $\mathrm{H}+\mathrm{C}_{2} \mathrm{H} \rightarrow \mathrm{C}_{2} \mathrm{H}_{2}$ & $3.00(-10)$ & 0 & 0 \\
\hline C34 (a) & $\mathrm{H}+\mathrm{C}_{2} \mathrm{H}_{2}+\mathrm{N}_{2} \rightarrow \mathrm{C}_{2} \mathrm{H}_{3}+\mathrm{N}_{2}$ & $5.69(-31)$ & -0.021 & -1120 \\
\hline C35 (a) & $\mathrm{H}+\mathrm{C}_{2} \mathrm{H}_{4}+\mathrm{N}_{2} \rightarrow \mathrm{C}_{2} \mathrm{H}_{5}+\mathrm{N}_{2}$ & $4.87(-27)$ & -1.12 & -1440 \\
\hline $\mathrm{C} 36$ & $\mathrm{H}+\mathrm{C}_{2} \mathrm{H}_{4} \rightarrow \mathrm{C}_{2} \mathrm{H}_{3}+\mathrm{H}_{2}$ & $9.00(-10)$ & 0 & -7500 \\
\hline C37 & $\mathrm{H}+\mathrm{C}_{2} \mathrm{H}_{5} \rightarrow \mathrm{C}_{2} \mathrm{H}_{4}+\mathrm{H}_{2}$ & $3.00(-12)$ & 0 & 0 \\
\hline C38 & $\mathrm{H}+\mathrm{C}_{2} \mathrm{H}_{6} \rightarrow \mathrm{H}_{2}+\mathrm{C}_{2} \mathrm{H}_{5}$ & $2.40(-15)$ & 1.5 & -3730 \\
\hline C39 & $\mathrm{H}+\mathrm{CH}_{2}=\mathrm{C}=\mathrm{CH}_{2} \rightarrow \mathrm{CH}_{2}=\mathrm{CHCH}_{2}$ & $2.00(-13)$ & 0 & -1510 \\
\hline $\mathrm{C} 40$ & $\mathrm{H}+\mathrm{CH}_{2}=\mathrm{C}=\mathrm{CH}_{2} \rightarrow \mathrm{CH}_{2}=\mathrm{CCH}_{3}$ & $1.41(-11)$ & 0 & -1010 \\
\hline $\mathrm{C} 41$ & $\mathrm{H}+\mathrm{CH}_{3} \mathrm{C} \equiv \mathrm{CH} \rightarrow \mathrm{CH}_{2}=\mathrm{CHCH}_{2}$ & $3.32(-11)$ & 0 & -1200 \\
\hline $\mathrm{C} 42$ & $\mathrm{H}+\mathrm{CH}_{3} \mathrm{C} \equiv \mathrm{CH} \rightarrow \mathrm{CH}_{3} \mathrm{CH}=\mathrm{CH}$ & $9.61(-12)$ & 0 & -1560 \\
\hline $\mathrm{C} 43$ & $\mathrm{H}+\mathrm{CH}_{3} \mathrm{C} \equiv \mathrm{CH} \rightarrow \mathrm{CH}_{2}=\mathrm{CCH}_{3}$ & $1.08(-11)$ & 0 & -1010 \\
\hline $\mathrm{C} 44$ & $\mathrm{H}+\mathrm{CH}_{2}=\mathrm{CCH}_{3} \rightarrow \mathrm{H}_{2}+\mathrm{CH}_{2}=\mathrm{C}=\mathrm{CH}_{2}$ & $2.00(-11)$ & 0 & 0 \\
\hline $\mathrm{C} 45$ & $\mathrm{H}+\mathrm{C}_{3} \mathrm{H}_{6} \rightarrow \mathrm{CH}_{2}=\mathrm{CCH}_{3}+\mathrm{H}_{2}$ & $6.48(-19)$ & 2.5 & -2930 \\
\hline $\mathrm{C} 46$ & $\mathrm{H}+\mathrm{C}_{3} \mathrm{H}_{6} \rightarrow \mathrm{n}-\mathrm{C}_{3} \mathrm{H}_{7}$ & $2.16(-11)$ & 0 & -1640 \\
\hline C47 & $\mathrm{H}+$ iso- $\mathrm{C}_{3} \mathrm{H}_{7} \rightarrow \mathrm{C}_{3} \mathrm{H}_{6}+\mathrm{H}_{2}$ & $6.00(-12)$ & 0 & 0 \\
\hline $\mathrm{C} 48$ & $\mathrm{H}+\mathrm{n}-\mathrm{C}_{3} \mathrm{H}_{7} \rightarrow \mathrm{H}_{2}+\mathrm{C}_{3} \mathrm{H}_{6}$ & $3.00(-12)$ & 0 & 0 \\
\hline C49 & $\mathrm{CH}+\mathrm{H}_{2} \rightarrow \mathrm{CH}_{2}+\mathrm{H}$ & $1.20(-10)$ & 0 & -1760 \\
\hline C50 & $\mathrm{CH}+\mathrm{H}_{2} \rightarrow \mathrm{CH}_{3}$ & $1.20(-10)$ & 0 & -1760 \\
\hline C51 & $\mathrm{CH}+\mathrm{CH}_{4} \rightarrow \mathrm{C}_{2} \mathrm{H}_{4}+\mathrm{H}$ & $5.00(-11)$ & 0 & 200 \\
\hline C52 & $\mathrm{CH}+\mathrm{C}_{2} \mathrm{H}_{2} \rightarrow \mathrm{H}+\mathrm{C}_{2} \mathrm{H}_{3}$ & $3.50(-10)$ & 0 & 61 \\
\hline C53 & $\mathrm{CH}+\mathrm{C}_{2} \mathrm{H}_{4} \rightarrow \mathrm{CH}_{2}=\mathrm{CHCH}_{2}$ & $2.20(-10)$ & 0 & 173 \\
\hline C54 & $\mathrm{CH}+\mathrm{C}_{2} \mathrm{H}_{6} \rightarrow \mathrm{n}-\mathrm{C}_{3} \mathrm{H}_{7}$ & $1.80(-11)$ & 0 & 132 \\
\hline C55 & $\mathrm{CH}+\mathrm{CH}_{3} \mathrm{C} \equiv \mathrm{CH} \rightarrow \mathrm{C}+\mathrm{CH}_{2}=\mathrm{CCH}_{3}$ & $4.60(-10)$ & 0 & 0 \\
\hline C56 & $\mathrm{CH}_{2}+\mathrm{CH}_{2} \rightarrow \mathrm{C}_{2} \mathrm{H}_{2}+\mathrm{H}_{2}$ & $2.00(-11)$ & 0 & -400 \\
\hline C57 & $\mathrm{CH}_{2}+\mathrm{CH}_{2} \rightarrow \mathrm{C}_{2} \mathrm{H}_{2}+\mathrm{H}+\mathrm{H}$ & $1.80(-10)$ & 0 & -400 \\
\hline C58 & $\mathrm{CH}_{2}+\mathrm{CH}_{3} \rightarrow \mathrm{C}_{2} \mathrm{H}_{4}+\mathrm{H}$ & $7.00(-11)$ & 0 & 0 \\
\hline C59 & $\mathrm{CH}_{2}+\mathrm{C}_{2} \mathrm{H} \rightarrow \mathrm{CH}+\mathrm{C}_{2} \mathrm{H}_{2}$ & $3.00(-11)$ & 0 & 0 \\
\hline C60 & $\mathrm{CH}_{2}+\mathrm{C}_{2} \mathrm{H}_{2} \rightarrow \mathrm{CH}_{3} \mathrm{C} \equiv \mathrm{CH}$ & $2.00(-11)$ & 0 & -3330 \\
\hline C61 & $\mathrm{CH}_{2}+\mathrm{C}_{2} \mathrm{H}_{3} \rightarrow \mathrm{CH}_{3}+\mathrm{C}_{2} \mathrm{H}_{2}$ & $3.00(-11)$ & 0 & 0 \\
\hline C62 & $\mathrm{CH}_{2}+\mathrm{C}_{2} \mathrm{H}_{4} \rightarrow \mathrm{C}_{3} \mathrm{H}_{6}$ & $5.20(-12)$ & 0 & -2600 \\
\hline C63 & $\mathrm{CH}_{2}+\mathrm{C}_{2} \mathrm{H}_{5} \rightarrow \mathrm{CH}_{3}+\mathrm{C}_{2} \mathrm{H}_{4}$ & $3.00(-11)$ & 0 & 0 \\
\hline C64 & $\mathrm{CH}_{2}+\mathrm{CH}_{2}=\mathrm{CHCH}_{2} \rightarrow \mathrm{C}_{2} \mathrm{H}_{3}+\mathrm{C}_{2} \mathrm{H}_{4}$ & $8.00(-11)$ & 0 & 0 \\
\hline C65 & $\mathrm{CH}_{2}+\mathrm{CH}_{2}=\mathrm{CHCH}_{2} \rightarrow(\mathrm{E}) \mathrm{CH}_{2}=\mathrm{CHCH}=\mathrm{CH}_{2}+\mathrm{H}$ & $4.00(-10)$ & 0 & 0 \\
\hline C66 & $\mathrm{CH}_{2}+\mathrm{C}_{3} \mathrm{H}_{6} \rightarrow \mathrm{CH}_{3} \mathrm{CH}=\mathrm{CHCH}_{3}$ & $2.71(-12)$ & 0 & -2660 \\
\hline C67 & $\mathrm{CH}_{2}+$ iso- $\mathrm{C}_{3} \mathrm{H}_{7} \rightarrow \mathrm{C}_{3} \mathrm{H}_{6}+\mathrm{CH}_{3}$ & $5.00(-11)$ & 0 & 0 \\
\hline C68 & $\mathrm{CH}_{2}+\mathrm{n}-\mathrm{C}_{3} \mathrm{H}_{7} \rightarrow \mathrm{C}_{3} \mathrm{H}_{6}+\mathrm{CH}_{3}$ & $3.00(-12)$ & 0 & 0 \\
\hline C69 & $\mathrm{CH}_{2}+\mathrm{n}-\mathrm{C}_{3} \mathrm{H}_{7} \rightarrow \mathrm{C}_{2} \mathrm{H}_{4}+\mathrm{C}_{2} \mathrm{H}_{5}$ & $3.00(-11)$ & 0 & 0 \\
\hline $\mathrm{C} 70$ & $\mathrm{CH}_{3}+\mathrm{H}_{2} \rightarrow \mathrm{CH}_{4}+\mathrm{H}$ & $1.14(-20)$ & 2.74 & -4740 \\
\hline C71 & $\mathrm{CH}_{3}+\mathrm{C}_{2} \mathrm{H} \rightarrow \mathrm{CH}_{2}=\mathrm{C}=\mathrm{CH}+\mathrm{H}$ & $4.00(-11)$ & 0 & 0 \\
\hline
\end{tabular}


Propane dissociation in a nitrogen plasma

\begin{tabular}{|c|c|c|c|c|}
\hline $\mathrm{C} 72$ & $\mathrm{CH}_{3}+\mathrm{C}_{2} \mathrm{H}_{2} \rightarrow \mathrm{CH}_{2}=\mathrm{CHCH}_{2}$ & $1.00(-12)$ & 0 & -3900 \\
\hline $\mathrm{C} 73$ & $\mathrm{CH}_{3}+\mathrm{C}_{2} \mathrm{H}_{3} \rightarrow \mathrm{C}_{2} \mathrm{H}_{2}+\mathrm{CH}_{4}$ & $6.50(-13)$ & 0 & 0 \\
\hline C74 & $\mathrm{CH}_{3}+\mathrm{C}_{2} \mathrm{H}_{4} \rightarrow \mathrm{CH}_{4}+\mathrm{C}_{2} \mathrm{H}_{3}$ & $5.90(-12)$ & 0 & -5600 \\
\hline $\mathrm{C} 75$ & $\mathrm{CH}_{3}+\mathrm{C}_{2} \mathrm{H}_{4} \rightarrow \mathrm{n}-\mathrm{C}_{3} \mathrm{H}_{7}$ & $3.50(-13)$ & 0 & -3700 \\
\hline C76 & $\mathrm{CH}_{3}+\mathrm{C}_{2} \mathrm{H}_{5} \rightarrow \mathrm{CH}_{4}+\mathrm{C}_{2} \mathrm{H}_{4}$ & $1.90(-12)$ & 0 & 0 \\
\hline C77 & $\mathrm{CH}_{3}+\mathrm{C}_{2} \mathrm{H}_{6} \rightarrow \mathrm{CH}_{4}+\mathrm{C}_{2} \mathrm{H}_{5}$ & $2.50(-31)$ & 6.0 & -3040 \\
\hline $\mathrm{C} 78$ & $\mathrm{CH}_{3}+\mathrm{CH}_{2}=\mathrm{C}=\mathrm{CH} \rightarrow \mathrm{CH}_{2}=\mathrm{C}=\mathrm{CHCH}_{3}$ & $2.50(-12)$ & 0 & 0 \\
\hline C79 & $\mathrm{CH}_{3}+\mathrm{CH}_{2}=\mathrm{CHCH}_{2} \rightarrow \mathrm{CH}_{4}+\mathrm{CH}_{2}=\mathrm{C}=\mathrm{CH}_{2}$ & $5.00(-12)$ & -0.32 & 66 \\
\hline $\mathrm{C} 80$ & $\mathrm{CH}_{3}+$ iso- $\mathrm{C}_{3} \mathrm{H}_{7} \rightarrow$ iso- $\mathrm{C}_{4} \mathrm{H}_{10}$ & $2.26(-9)$ & -0.68 & 0 \\
\hline $\mathrm{C} 81$ & $\mathrm{CH}_{3}+$ iso- $\mathrm{C}_{3} \mathrm{H}_{7} \rightarrow \mathrm{C}_{3} \mathrm{H}_{6}+\mathrm{CH}_{4}$ & $1.56(-13)$ & 0.68 & 0 \\
\hline $\mathrm{C} 82$ & $\mathrm{CH}_{3}+\mathrm{n}-\mathrm{C}_{3} \mathrm{H}_{7} \rightarrow \mathrm{n}-\mathrm{C}_{4} \mathrm{H}_{10}$ & $3.20(-10)$ & -0.32 & 0 \\
\hline $\mathrm{C} 83$ & $\mathrm{CH}_{3}+\mathrm{n}-\mathrm{C}_{3} \mathrm{H}_{7} \rightarrow \mathrm{C}_{3} \mathrm{H}_{6}+\mathrm{CH}_{4}$ & $4.96(-13)$ & -0.32 & 0 \\
\hline C84 & $\mathrm{C}_{2} \mathrm{H}+\mathrm{H}_{2} \rightarrow \mathrm{C}_{2} \mathrm{H}_{2}+\mathrm{H}$ & $1.80(-11)$ & 0 & -1090 \\
\hline $\mathrm{C} 85$ & $\mathrm{C}_{2} \mathrm{H}+\mathrm{CH}_{4} \rightarrow \mathrm{C}_{2} \mathrm{H}_{2}+\mathrm{CH}_{3}$ & $3.00(-12)$ & 0 & -250 \\
\hline C86 & $\mathrm{C}_{2} \mathrm{H}+\mathrm{C}_{2} \mathrm{H} \rightarrow \mathrm{C}_{2}+\mathrm{C}_{2} \mathrm{H}_{2}$ & $3.00(-12)$ & 0 & 0 \\
\hline C87 & $\mathrm{C}_{2} \mathrm{H}+\mathrm{C}_{2} \mathrm{H} \rightarrow \mathrm{HC} \equiv \mathrm{CC} \equiv \mathrm{CH}$ & $3.00(-11)$ & 0 & 0 \\
\hline $\mathrm{C} 88$ & $\mathrm{C}_{2} \mathrm{H}+\mathrm{C}_{2} \mathrm{H}_{2} \rightarrow \mathrm{HC} \equiv \mathrm{CC} \equiv \mathrm{CH}+\mathrm{H}$ & $1.50(-10)$ & 0 & 0 \\
\hline C89 & $\mathrm{C}_{2} \mathrm{H}+\mathrm{C}_{2} \mathrm{H}_{3} \rightarrow \mathrm{C}_{2} \mathrm{H}_{2}+\mathrm{C}_{2} \mathrm{H}_{2}$ & $1.60(-12)$ & 0 & 0 \\
\hline C90 & $\mathrm{C}_{2} \mathrm{H}+\mathrm{C}_{2} \mathrm{H}_{3} \rightarrow \mathrm{CH}_{2}=\mathrm{CHC} \equiv \mathrm{CH}$ & $3.00(-11)$ & 0 & 0 \\
\hline C91 & $\mathrm{C}_{2} \mathrm{H}+\mathrm{C}_{2} \mathrm{H}_{4} \rightarrow \mathrm{CH}_{2}=\mathrm{CHC} \equiv \mathrm{CH}+\mathrm{H}$ & $2.00(-11)$ & 0 & 0 \\
\hline C92 & $\mathrm{C}_{2} \mathrm{H}+\mathrm{C}_{2} \mathrm{H}_{5} \rightarrow \mathrm{C}_{2} \mathrm{H}_{2}+\mathrm{C}_{2} \mathrm{H}_{4}$ & $3.00(-12)$ & 0 & 0 \\
\hline C93 & $\mathrm{C}_{2} \mathrm{H}+\mathrm{C}_{2} \mathrm{H}_{5} \rightarrow \mathrm{CH}_{2}=\mathrm{C}=\mathrm{CH}+\mathrm{CH}_{3}$ & $3.00(-12)$ & 0 & 0 \\
\hline C94 & $\mathrm{C}_{2} \mathrm{H}+\mathrm{C}_{2} \mathrm{H}_{6} \rightarrow \mathrm{C}_{2} \mathrm{H}_{2}+\mathrm{C}_{2} \mathrm{H}_{5}$ & $6.00(-12)$ & 0 & 0 \\
\hline C95 (b) & $\mathrm{C}_{2} \mathrm{H}+\mathrm{CH}_{2}=\mathrm{CHCH}_{2} \rightarrow \mathrm{CH}_{2}=\mathrm{CHCH}_{2} \mathrm{C} \equiv \mathrm{CH}$ & $8.00(-11)$ & 0 & 0 \\
\hline C96 & $\mathrm{C}_{2} \mathrm{H}+\mathrm{CH}_{2}=\mathrm{CHCH}_{2} \rightarrow \mathrm{CH}_{2}=\mathrm{C}=\mathrm{CH}_{2}+\mathrm{C}_{2} \mathrm{H}_{2}$ & $1.20(-11)$ & 0 & 0 \\
\hline C97 & $\mathrm{C}_{2} \mathrm{H}+\mathrm{C}_{3} \mathrm{H}_{6} \rightarrow \mathrm{CH}_{3} \mathrm{C} \equiv \mathrm{CH}+\mathrm{C}_{2} \mathrm{H}_{3}$ & $2.00(-11)$ & 0 & 0 \\
\hline C98 & $\mathrm{C}_{2} \mathrm{H}+\mathrm{C}_{3} \mathrm{H}_{6} \rightarrow \mathrm{CH}_{2}=\mathrm{CHCH}_{2}+\mathrm{C}_{2} \mathrm{H}_{2}$ & $6.00(-12)$ & 0 & 0 \\
\hline C99 & $\mathrm{C}_{2} \mathrm{H}+\mathrm{C}_{3} \mathrm{H}_{6} \rightarrow \mathrm{C}_{2} \mathrm{H}_{5} \mathrm{C} \equiv \mathrm{CH}+\mathrm{CH}$ & $2.00(-11)$ & 0 & 0 \\
\hline C100 & $\mathrm{C}_{2} \mathrm{H}+\mathrm{C}_{3} \mathrm{H}_{6} \rightarrow \mathrm{CH}_{3} \mathrm{CH}=\mathrm{CH}+\mathrm{C}_{2} \mathrm{H}_{2}$ & $2.00(-12)$ & 0 & 0 \\
\hline C101 & $\mathrm{C}_{2} \mathrm{H}+\mathrm{C}_{3} \mathrm{H}_{6} \rightarrow \mathrm{CH}_{2}=\mathrm{CCH}_{3}+\mathrm{C}_{2} \mathrm{H}_{2}$ & $2.00(-12)$ & 0 & 0 \\
\hline C102 & $\mathrm{C}_{2} \mathrm{H}+$ iso- $\mathrm{C}_{3} \mathrm{H}_{7} \rightarrow \mathrm{C}_{3} \mathrm{H}_{6}+\mathrm{C}_{2} \mathrm{H}_{2}$ & $6.00(-12)$ & 0 & 0 \\
\hline C103 & $\mathrm{C}_{2} \mathrm{H}+\mathrm{n}-\mathrm{C}_{3} \mathrm{H}_{7} \rightarrow \mathrm{CH}_{2}=\mathrm{C}=\mathrm{CH}+\mathrm{C}_{2} \mathrm{H}_{5}$ & $2.00(-11)$ & 0 & 0 \\
\hline $\mathrm{C} 104$ & $\mathrm{C}_{2} \mathrm{H}+\mathrm{n}-\mathrm{C}_{3} \mathrm{H}_{7} \rightarrow \mathrm{C}_{3} \mathrm{H}_{6}+\mathrm{C}_{2} \mathrm{H}_{2}$ & $1.00(-11)$ & 0 & 0 \\
\hline C105 & $\mathrm{C}_{2} \mathrm{H}_{3}+\mathrm{H}_{2} \rightarrow \mathrm{C}_{2} \mathrm{H}_{4}+\mathrm{H}$ & $5.00(-20)$ & 2.63 & -4300 \\
\hline C106 & $\mathrm{C}_{2} \mathrm{H}_{3}+\mathrm{CH}_{4} \rightarrow \mathrm{C}_{2} \mathrm{H}_{4}+\mathrm{CH}_{3}$ & $2.50(-24)$ & 4.02 & -2750 \\
\hline C107 & $\mathrm{C}_{2} \mathrm{H}_{3}+\mathrm{C}_{2} \mathrm{H}_{5} \rightarrow \mathrm{C}_{2} \mathrm{H}_{4}+\mathrm{C}_{2} \mathrm{H}_{4}$ & $8.00(-13)$ & 0 & 0 \\
\hline C108 & $\mathrm{C}_{2} \mathrm{H}_{3}+\mathrm{C}_{2} \mathrm{H}_{5} \rightarrow \mathrm{C}_{2} \mathrm{H}+\mathrm{C}_{2} \mathrm{H}_{6}$ & $8.00(-13)$ & 0 & 0 \\
\hline C109 & $\mathrm{C}_{2} \mathrm{H}_{3}+\mathrm{C}_{2} \mathrm{H}_{6} \rightarrow \mathrm{C}_{2} \mathrm{H}_{4}+\mathrm{C}_{2} \mathrm{H}_{5}$ & $1.00(-21)$ & 3.3 & -5290 \\
\hline $\mathrm{C} 110$ & $\mathrm{C}_{2} \mathrm{H}_{3}+\mathrm{C}_{3} \mathrm{H}_{6} \rightarrow(\mathrm{E}) \mathrm{CH}_{2}=\mathrm{CHCH}=\mathrm{CH}_{2}+\mathrm{CH}_{3}$ & $1.20(-12)$ & 0 & -2520 \\
\hline C111 & $\mathrm{C}_{2} \mathrm{H}_{3}+$ iso- $\mathrm{C}_{3} \mathrm{H}_{7} \rightarrow\left(\mathrm{CH}_{3}\right)_{2} \mathrm{CHCH}=\mathrm{CH}_{2}$ & $1.41(-9)$ & -0.7 & 0 \\
\hline $\mathrm{C} 112$ & $\mathrm{C}_{2} \mathrm{H}_{3}+$ iso- $\mathrm{C}_{3} \mathrm{H}_{7} \rightarrow \mathrm{C}_{2} \mathrm{H}_{4}+\mathrm{C}_{3} \mathrm{H}_{6}$ & $2.54(-10)$ & -0.7 & 0 \\
\hline
\end{tabular}




\begin{tabular}{|c|c|c|c|c|}
\hline $\mathrm{C} 113$ & $\mathrm{C}_{2} \mathrm{H}_{3}+\mathrm{n}-\mathrm{C}_{3} \mathrm{H}_{7} \rightarrow \mathrm{CH}_{3}\left(\mathrm{CH}_{2}\right)_{2} \mathrm{CH}=\mathrm{CH}_{2}$ & $1.60(-11)$ & 0 & 0 \\
\hline $\mathrm{C} 114$ & $\mathrm{C}_{2} \mathrm{H}_{3}+\mathrm{n}-\mathrm{C}_{3} \mathrm{H}_{7} \rightarrow \mathrm{C}_{3} \mathrm{H}_{6}+\mathrm{C}_{2} \mathrm{H}_{4}$ & $2.00(-12)$ & 0 & 0 \\
\hline $\mathrm{C} 115$ & $\mathrm{C}_{2} \mathrm{H}_{5}+\mathrm{C}_{2} \mathrm{H}_{2} \rightarrow$ radical products & $5.60(-14)$ & 0 & -3520 \\
\hline $\mathrm{C} 116$ & $\mathrm{C}_{2} \mathrm{H}_{5}+\mathrm{C}_{2} \mathrm{H}_{4} \rightarrow 1-\mathrm{C}_{4} \mathrm{H}_{9}$ & $1.80(-13)$ & 0 & -3670 \\
\hline C117 & $\mathrm{C}_{2} \mathrm{H}_{5}+\mathrm{C}_{2} \mathrm{H}_{5} \rightarrow \mathrm{C}_{2} \mathrm{H}_{6}+\mathrm{C}_{2} \mathrm{H}_{4}$ & $2.40(-12)$ & 0 & 0 \\
\hline C118 & $\mathrm{C}_{2} \mathrm{H}_{5}+\mathrm{CH}_{2}=\mathrm{CHCH}_{2} \rightarrow \mathrm{C}_{2} \mathrm{H}_{6}+\mathrm{CH}_{2}=\mathrm{C}=\mathrm{CH}_{2}$ & $1.60(-12)$ & 0 & 66 \\
\hline C119 & $\mathrm{C}_{2} \mathrm{H}_{5}+\mathrm{CH}_{2}=\mathrm{CHCH}_{2} \rightarrow \mathrm{C}_{2} \mathrm{H}_{4}+\mathrm{C}_{3} \mathrm{H}_{6}$ & $4.30(-12)$ & 0 & 66 \\
\hline $\mathrm{C} 120$ & $\mathrm{C}_{2} \mathrm{H}_{5}+$ iso- $\mathrm{C}_{3} \mathrm{H}_{7} \rightarrow$ iso- $\mathrm{C}_{5} \mathrm{H}_{12}$ & $1.91(-10)$ & -0.35 & 0 \\
\hline $\mathrm{C} 121$ & $\mathrm{C}_{2} \mathrm{H}_{5}+$ iso- $\mathrm{C}_{3} \mathrm{H}_{7} \rightarrow \mathrm{C}_{3} \mathrm{H}_{6}+\mathrm{C}_{2} \mathrm{H}_{6}$ & $3.82(-11)$ & -0.35 & 0 \\
\hline $\mathrm{C} 122$ & $\mathrm{C}_{2} \mathrm{H}_{5}+\mathrm{n}-\mathrm{C}_{3} \mathrm{H}_{7} \rightarrow \mathrm{n}-\mathrm{C}_{5} \mathrm{H}_{12}$ & $3.30(-11)$ & 0 & 0 \\
\hline $\mathrm{C} 123$ & $\mathrm{C}_{2} \mathrm{H}_{5}+\mathrm{n}-\mathrm{C}_{3} \mathrm{H}_{7} \rightarrow \mathrm{C}_{3} \mathrm{H}_{6}+\mathrm{C}_{2} \mathrm{H}_{6}$ & $2.41(-12)$ & 0 & 0 \\
\hline $\mathrm{C} 124$ & $\mathrm{CH}_{3} \mathrm{C} \equiv \mathrm{CH}+$ iso- $\mathrm{C}_{3} \mathrm{H}_{7} \rightarrow$ radical products & $8.30(-15)$ & 0 & 0 \\
\hline $\mathrm{C} 125$ & $\mathrm{CH}_{2}=\mathrm{CHCH}_{2}+\mathrm{CH}_{2}=\mathrm{CHCH}_{2} \rightarrow \mathrm{CH}_{2}=\mathrm{C}=\mathrm{CH}_{2}+\mathrm{C}_{3} \mathrm{H}_{6}$ & $1.00(-13)$ & 0 & 132 \\
\hline $\mathrm{C} 126$ & $\mathrm{CH}_{2}=\mathrm{CHCH}_{2}+$ iso- $\mathrm{C}_{3} \mathrm{H}_{7} \rightarrow \mathrm{C}_{3} \mathrm{H}_{6}+\mathrm{C}_{3} \mathrm{H}_{6}$ & $3.80(-11)$ & -0.35 & 66 \\
\hline $\mathrm{C} 127$ & $\mathrm{CH}_{2}=\mathrm{CHCH}_{2}+$ iso- $\mathrm{C}_{3} \mathrm{H}_{7} \rightarrow\left(\mathrm{CH}_{3}\right)_{2} \mathrm{CHCH}_{2} \mathrm{CH}=\mathrm{CH}_{2}$ & $1.90(-10)$ & -0.35 & 66 \\
\hline C128 & $\mathrm{CH}_{2}=\mathrm{CHCH}_{2}+\mathrm{n}-\mathrm{C}_{3} \mathrm{H}_{7} \rightarrow \mathrm{C}_{3} \mathrm{H}_{6}+\mathrm{C}_{3} \mathrm{H}_{6}$ & $2.40(-12)$ & 0 & 66 \\
\hline C129 & $\mathrm{CH}_{2}=\mathrm{CHCH}_{2}+\mathrm{n}-\mathrm{C}_{3} \mathrm{H}_{7} \rightarrow \mathrm{CH}_{3}\left(\mathrm{CH}_{2}\right)_{3} \mathrm{CH}=\mathrm{CH}_{2}$ & $3.40(-11)$ & 0 & 66 \\
\hline $\mathrm{C} 130$ & iso- $\mathrm{C}_{3} \mathrm{H}_{7}+$ iso- $\mathrm{C}_{3} \mathrm{H}_{7} \rightarrow\left(\mathrm{CH}_{3}\right)_{2} \mathrm{CHCH}\left(\mathrm{CH}_{3}\right)_{2}$ & $5.40(-10)$ & -0.7 & 0 \\
\hline C131 & iso- $\mathrm{C}_{3} \mathrm{H}_{7}+\mathrm{n}-\mathrm{C}_{3} \mathrm{H}_{7} \rightarrow$ iso- $\mathrm{C}_{6} \mathrm{H}_{14}$ & $2.13(-10)$ & -0.35 & 0 \\
\hline C132 & $\mathrm{n}-\mathrm{C}_{3} \mathrm{H}_{7}+\mathrm{n}-\mathrm{C}_{3} \mathrm{H}_{7} \rightarrow \mathrm{n}-\mathrm{C}_{6} \mathrm{H}_{14}$ & $1.69(-11)$ & 0 & 0 \\
\hline
\end{tabular}
(a) : rate constant only valid for the experimental conditions (total pressure and temperature values) of the present work.
(b) : exit route suppositional.




\section{References}

[1] Yamamoto T 1999 J. Haz. Mater. B 67165

[2] Dorai R, and Kushner M 2000 J. Appl. Phys. 883739

[3] Shin H-H, and Yoon W-S 2003 Plasma Chem. Plasma Process. 23681

[4] Jarrige J, and Vervisch P 2006 J. Appl. Phys. 99113303

[5] Hill S, Whitehead J, and Zhang K 2007 Plasma Process. Polym. 4710

[6] Aubry O, and Cormier J-M 2009 Plasma Chem. Plasma Process. 2913

[7] Wang F, Jiang C, Kuthi A, Gundersen M, Brophy C, Sinibaldi J, and Lee L $200442^{\text {nd }}$ AIAA Aerospace Sciences Meeting and Exhibit (Reno, Nevada, USA, 5-8 January 2004) Paper AIAA2004-0834

[8] Rosocha L, Coates D, Platts D, and Stange S 2004 Phys. Plasmas 112950

[9] Starikovskaia S 2006 J. Phys. D : Appl. Phys. 39 R265

[10] Pancheshnyi S, Lacoste D, Bourdon A, and Laux C 2006 IEEE Trans. Plasma Sci. 342478

[11] Kim Y, Ferreri V, Rosocha L, Anderson G, Abbate S, and Kim K-T 2006 IEEE Trans. Plasma Sci. 342532

[12] Kosarev I, Aleksandrov N, Kindysheva S, Starikovskaia S, and Starikovskii A 2009 Comb. Flame 156221

[13] Adamovich I, Choi I, Jiang N, Kim J-H, Keshav S, Lempert W, Mintussov E, Nishihara M, Saminy M, and Uddi M 2009 Plasma Sources Sci. Technol. 18034018

[14] Chingsungnoen A, Wilson J, Amornkitbamrung V, Thomas C, and Burinprakhon T 2007 Plasma Sources Sci. Technol. 16434

[15] Chouki A 1994 PhD Thesis Université Paul Sabatier

[16] Huo W, and Kim Y-K 1999 IEEE Trans. Plasma Sci. 271225

[17] Shirai T, Tabata T, Tawara H, and Itikawa Y 2002 At. Data Nucl. Data Tables 80147

[18] Janev R, and Reiter D 2004 Collision Processes of Hydrocarbon Species in Hydrogen Plasmas: II. Ethane \& Propane Families, Juel-Report 4005, http://www.eirene.de

[19] Callear A, and Wood P 1971 Trans. Faraday Soc. 67272

[20] Herron J 1999 J. Phys. Chem. Ref. Data 281453

[21] Lacour B, Puech V, and Pasquiers S 2003 Recent Res. Devel. Appl. Phys. 6149

[22] Magne L, Blin-Simiand N, Gadonna K, Jeanney P, Jorand F, Pasquiers S, and Postel C 2009 Europ. Phys. J. : Appl. Phys. 4722816

[23] Magne L, Pasquiers S, Blin-Simiand N, and Postel C 2007 J. Phys. D : Appl. Phys. 403112

[24] Magne L, Pasquiers S, Gadonna K, Jeanney P, Blin-Simiand N, Jorand F, and Postel C $2009 \mathrm{~J}$. Phys. D : Appl. Phys. 42165203

[25] Piper L 1987 J. Chem. Phys. 871625

[26] Fresnet F, Baravian G, Magne L, Pasquiers S, Postel C, Puech V, and Rousseau A 2000 Appl. Phys. Lett. 774118

[27] Magne L, Pasquiers S, Edon V, Jorand F, Postel C, and Amorim J 2005 J. Phys. D : Appl. Phys. 383446

[28] Rosocha L, and Korzekwa R 1999 J. Adv. Oxid. Technol. 4247

[29] Yan K, van Heesch E, Pemen A, and Huijbrechts A 2000 Plasma Chem. Plasma Proc. 21107 
[30] Blin-Simiand N, Jorand F, Magne L, Pasquiers S, Postel C, and Vacher J-R 2008 Plasma Chem. Plasma Proc. 28429

[31] Blin-Simiand N, Pasquiers S, Jorand F, Postel C, and Vacher J-R 2009 J. Phys. D : Appl. Phys. 42122003

[32] Blin-Simiand N, Koeta O, Pasquiers S, Bary A, Jorand F, Magne L, and Postel C 2009 XIXth International Symposium on Plasma Chemistry (Bochum, Allemagne).

[33] Blin-Simiand N, Jorand F, Magne L, Pasquiers S, and Postel C 2008 11th International Symposium on High Pressure Low Temperature Plasma Chemistry (St.Pierre d'Oléron, France).

[34] Rozoy M, Postel C, and Puech V 1999 Plasma Sources Sci. Technol. 8337

[35] Fresnet F, Baravian G, Magne L, Pasquiers S, Postel C, Puech V and Rousseau A 2002 Plasma Sources Sci. Technol. 11152

[36] Pasquiers S, Postel C, Magne L, Puech V and Lombardi G 2004 J. Adv. Oxid. Technlol. 7108

[37] Kossyi I, Kostinsky A, Matveyev A, and Silakov V 1992 Plasma Sources Sci. Technol. 1207

[38] IUPAC Subcommittee on Gas Kinetic Data Evaluation - $\underline{\text { http://www.iupac- }}$ kinetic.ch.cam.ac.uk/

[39] Mallard W, Westley F, Herron J, Hampson R and Frizzell D 1998 NIST Chemical Kinetics Database (version 2Q98) (Gaithersburg, M D: National Institute of Standards and Technology) and on the web : http://kinetics.nist.gov/kinetics/index.jsp

[40] Herron J 1988 J. Phys. Chem. Ref. Data 17967

[41] Anicich V 1993 J. Phys. Chem. Ref. Data 221469

[42] Tsang W 1988 J. Phys. Chem. Ref. Data 17887

[43] Meyer J, Klosterboer D, and Setser D 1971 J. Chem. Phys. 552084

[44] Bohmer E, and Hack W 1991 Z. Phys. Chem. 17015

[45] Clark W, and Setser D 1980 . J. Phys. Chem. 842225

[46] Golde M 1988 Int. J. Chem. Kin. 2075

[47] Tao W, Golde M, Ho G., and Moyle A 1987 J. Chem. Phys. 871045

[48] Golde M, Ho G, Tao W, and Thomas J 1989 J. Phys. Chem. 931112

[49] Pintassilgo C, Jaoul C, Loureiro J, Belmonte T, and Czerwiec T 2007 J. Phys. D : Appl. Phys. 403620

[50] Pringle K, Whitehead J, Wilman J, and Wu J 2004 Plasma Chem. Plasma Proc. 24421

[51] Jauberteau J, Jauberteau I, Cinelli M, and Aubreton J 2002 New J. Phys. 439.1

[52] Legrand J-C, Diamy A-M, Hrach R, and Hrachova V 1997 Contrib. Plasma Phys. 37521

[53] Frisch M et al. 2004 Gaussian 03, Revision C.02, Gaussian Inc., Wallingford, CT.

[54] Wu S, Lin J, Lee Y, and Yang X 2000 J. Chem. Phys. 1128027

[55] Galasso V 1992 Chem. Phys. 161189 